IJMS 16 (1), 229-259 (2009)

\title{
REAL EXCHANGE RATE AND TERMS OF TRADE: SOME EMPIRICAL EVIDENCE IN MALAYSIA, SINGAPORE, AND THAILAND
}

\author{
WONG HOCK TSEN \\ School of Business and Economics \\ Universiti Malaysia Sabah
}

\begin{abstract}
This study examined the relationship between real exchange rate and terms of trade in Malaysia, Singapore, and Thailand in two cases, namely a three-variable case and a four-variable case. The results of cointegration tests showed that there is long-run relationships among real exchange rate, terms of trade, and relative demand for Malaysia. Moreover, there is long-run relationship among real exchange rate, terms of trade, relative demand, and relative real interest rate for Malaysia and Thailand. The results of Granger causality showed that real exchange rate does not Granger cause terms of trade, however the result is mixed for Thailand. The contribution of terms of trade and relative demand to real exchange rate is mixed and small. Generally, the contribution of terms of trade to real exchange rate is greater than the contribution of relative demand in Singapore. For Thailand, relative demand is more important than terms of trade in the determination of real exchange rate. For Malaysia, the results are mixed.
\end{abstract}

Keywords: Real exchange rate; terms of trade; cointegration; causality.

\begin{abstract}
ABSTRAK
Kajian ini menguji hubungan di antara kadar pertukaran benar dan syarat perdagangan di Malaysia, Singapura, dan Thailand dalam dua kes, iaitu, kes tiga pemboleh ubah dan kes empat pemboleh ubah. Keputusan ujian kointegrasi menunjukkan bahawa terdapat hubungan jangka panjang antara kadar pertukaran benar, syarat perdagangan, dan permintaan relatif di Malaysia. Tambahan pula, terdapat hubungan jangka panjang antara kadar pertukaran benar, syarat perdagangan, permintaan relatif, dan kadar faedah benar relatif di Malaysia dan Thailand. Keputusan sebab-penyebab Granger menunjukkan bahawa kadar pertukaran benar tidak sebab-penyebab Granger syarat perdagangan, kecuali keputusan adalah bercampur bagi Thailand. Sumbangan
\end{abstract}


syarat perdagangan dan permintaan relatif terhadap kadar pertukaran benar adalah bercampur dan kecil. Pada umumnya, sumbangan syarat perdagangan terhadap kadar pertukaran benar adalah lebih besar berbanding dengan sumbangan permintaan relatif di Singapura. Manakala di Thailand, permintaan relatif adalah lebih penting berbanding dengan syarat perdagangan dalam penentuan kadar pertukaran benar. Untuk Malaysia, keputusan adalah bercampur.

Kata kunci: Kadar pertukaran benar; syarat perdagangan; kointegrasi; sebabpenyebab.

\section{INTRODUCTION}

It was argued that there is relationship between real exchange rate and terms of trade. Dungey (2004) used a latent factor model to examine the impact of terms of trade on real exchange rate volatility. The model is said to be able to capture the potential correlation between domestic and international conditions and terms of trade of an economy. The model is applied to an annual panel data of six Asian economies, namely Indonesia, Malaysia, Thailand, the Philippines, Pakistan, and Sri Lanka. The results showed that the contributions of terms of trade to real exchange rate volatility are higher in East Asian economies and almost negligible in Pakistan and Sri Lanka. The empirical evidence of the relationship between real exchange rate and terms of trade for developing and small open economies is limited, particularly the empirical evidence of time series data. In addition, the empirical evidence of the relationship between real exchange rate and terms of trade is mixed (Dungey, 2004).

The Balassa-Samuelson hypothesis (Balassa, 1964; Samuelson, 1964) postulated that real exchange rate can be explained by relative productivity of traded goods to non-traded goods. More specifically, an increase in relative productivity of traded goods to non-traded goods will lead to appreciation in real exchange rate. Conversely, a decrease in relative productivity of traded goods to non-traded goods will lead to depreciation in the real exchange rate. The Balassa-Samuelson hypothesis is said particularly relevant for developing economies where relative prices and productivities are likely to be more variable (Choudhri \& Khan, 2005). ${ }^{2}$ On the other hand, uncovered interest rate parity stated that exchange rate differential is the result of the expected interest rate differential (Levich, 2001 p.p. 155-160). Under these assumptions, the market's expectations are rational and unbiased, which implies that 
future exchange rate is equal to the expected future exchange rate plus a classical disturbance. Thus, uncovered interest rate parity can be reexpressed as exchange rate differential is equal to interest rate differential plus a classical disturbance (Levich, 2001, p.161).

This study examined the relationship between real exchange rate and terms of trade in Malaysia, Singapore, and Thailand using time series data. These economies are generally a small open economies. The degrees of openness to international trade (exports plus imports over gross domestic product) of these economies are different. Generally, Singapore was the most open to international trade. This was followed by Malaysia and Thailand (Table 1). For a small open economy, it is expected to have strong relationships between terms of trade and real exchange rate. Moreover, the impact of terms of trade on real exchange rate is said to be varied from economy to economy (Devereux \& Connolly, 1996). More specifically, this study examined the relationship between real exchange rate and terms of trade in two cases, namely a three-variable case and a four-variable case. In the first case, the relationship among real exchange rate, terms of trade, and relative demand are examined. In the second case, relative real interest rate is included in the estimation in addition to variables in the first case. Thus, the importance of relative real interest rate in the determination of real exchange rate in these economies was examined. The use of the two cases was also to examine the consistency of the results in this study.

Table 1: Openness to International Trade (\%)

\begin{tabular}{cccc}
\hline & Malaysia & Singapore & Thailand \\
\hline $1960-1969$ & 86.08 & 254.03 & 38.30 \\
$1970-1979$ & 88.58 & 251.57 & 41.62 \\
$1980-1989$ & 113.10 & 309.75 & 54.68 \\
$1990-1999$ & 178.13 & 279.39 & 87.07 \\
$2000-2005$ & 217.38 & 308.70 & 130.23 \\
\hline
\end{tabular}

Source: IFS, IMF.

The empirical evidence, especially the impact of terms of trade on real exchange rate, is relatively limited. Moreover, this study examined the important impact of relative demand and relative real interest rate on real exchange rate. The Dickey and Fuller (1979) (DF) and Phillips and Perron (1988) (PP) unit root test statistics were used to examine the stationarity of the data. The Johansen (1988) (J) cointegration method was used to examine the long-run relationship among variables in the system. The generalised forecast error variance decomposition and 
generalised impulse response function (Koop, Pesaran, \& Potter, 1996; Pesaran \& Shin, 1998) were used to examine the relationships of variables in a system.

The rest of this paper is structured as follows. The next section provides a literature review of real exchange rate and terms of trade. This is followed by the methodology, data used in this study, and the empirical results and discussions. Finally, this paper provides some concluding remarks.

\section{LITERATURE REVIEW OF REAL EXCHANGE RATE AND TERMS OF TRADE}

Sebastian and Van Wijnbergen (1987) used two small open economic models, namely a three good version of the Ricardo-Viner model and a three good model with full intersectoral factor mobility to examine the impact of terms of trade and tariff on the real exchange rate. Generally, it is not possible to know how real exchange rate will respond to the changes in terms of trade and tariff. Moreover, they demonstrated that it is incorrect to say that a decrease in terms of trade will lead to a decrease in real exchange rate. Johri and Lahiri (2008) augmented a standard two-country open economy model with learning-by-doing in production at the firm level to induce monopolistically competitive firms to endogensize the productivity effect of their price setting behaviour. Also, the model took into account habits in leisure, which make the labour supply decision dynamic, and added an additional source of propagation. The model produced a positive correlation between terms of trade and nominal exchange rate.

Amano and Van Norden (1995) examined the relationship between real exchange rate and terms of trade in Canada and the United States (US). The results showed that real exchange rate and terms of trade are cointegrated, and Granger causality runs from terms of trade to real exchange rate. Moreover, much of the variation in real exchange rate is attributable to the movements in terms of trade, and the influence of interest rate differential is secondary. Devereux and Connolly (1996) examined the relationship among commercial policy, real exchange rate, and terms of trade in four Latin American economies, namely Argentina, Colombia, Ecuador, and Venezuela. The results showed that the greater the elasticity of non-traded price with respect to import price, the larger is the impact of real exchange rate of import restrictions. This implied 
that import liberalisation would lead to a large depreciation in the equilibrium of real exchange rate. Moreover, the impact of terms of trade shock on real exchange rate varies from economy to economy. Generally, the impact of terms of trade on real exchange rate is small.

Broda (2004) examined the responses of real gross domestic product, real exchange rate, and consumer prices to changes of terms of trade across exchange rate regimes. The study uses an annual panel of 75 developing economies. The results among others showed that changes in terms of trade explain approximately $13 \%$ and $31 \%$ of exchange rate fluctuations in pegged and floating exchange rate regimes, respectively. Changes in terms of trade can explain a larger change of real exchange rate in floating exchange rate regime than in pegged exchange rate regime. Moreover, the importance of changes in terms of trade in explaining the variance of real gross domestic product, real exchange rates, and consumer prices varies considerably across time periods, but less across regions.

Dungey (2004) used a latent factor model to examine the impact of terms of trade on real exchange rate volatility. Real exchange rate volatility was modelled as a linear combination of three independent latent factors, namely a fixed (numeraire) factor, a country-specific factor, and a common world factor. Terms of trade changes were allowed to vary with both the country specific and common world factor (the variation with the numeraire factor is set to zero). The annual panel data of six Asian economies, namely Indonesia, Malaysia, Thailand, the Philippines, Pakistan, and Sri Lanka, were used. Bilateral exchange rates were expressed against the US dollar. The results showed the contributions of terms of trade to real exchange rate volatility ranging from higher in East Asian economies, to almost negligible in Pakistan and Sri Lanka.

Swift (2004, p. 743-744) showed that the small-economy assumption of an economy is unlikely to hold. If the exchange rate change is the result of a shock common to many small economies, the exchange rate change must be passed through to world prices, which in turn will lead to a change in terms of trade. Thus, terms of trade is not an exogenous variable in the system as it is influenced by world prices. The inclusion of terms of trade in the estimation will induce subsequent or second-round changes that magnify the degree of internal adjustment and consequently the size of the exchange rate change.

Choudhri and Khan (2005) examined the impact of the Balassa-Samuelson hypothesis in an annual panel data of 16 developing economies. The 
Balassa-Samuelson hypothesis provided an explanation for the longrun real exchange rate behaviour in terms of relative productivity of traded goods to non-traded goods. Real exchange rate would appreciate with an increase in relative productivity of traded goods to non-traded goods and vice versa. They found that differential in labour productivity exerts a significant impact on real exchange rate through its influence on relative price of non-traded goods. They also found that terms of trade is important in the determination of real exchange rate. However, it is sensitive to whether the sample includes crisis periods or not in the estimation. The Balassa-Samuelson hypothesis is an empirically useful framework for investigating the long-run behaviour of real exchange rate for developing economies (Choudhri \& Khan, 2005, p.p. 405-406).

Bagchi, Chortareas, and Miller (2004) examined the impact of terms of trade and the expected real interest rate differential on real exchange rate in eight small developed economies, namely Australia, Canada, Finland, Italy, New Zealand, Norway, Portugal, and Spain. The results showed that both terms of trade and the expected real interest rate differential affect real exchange rate in the long-run. However, the impact of terms of trade was found to be generally more consistent than the impact of the expected real interest rate differential. The speed of adjustment for the expected real interest rate differential in the error-correction model is quantitatively larger than it is for terms of trade. Chen and Chen (2007) examined the impact of real interest rate differential, productivity differential, and oil price on real exchange rate using a monthly panel of G7 countries from 1972:1 to 2005:10. The results showed that the impact of real interest rate differential and productivity differential on real exchange rate are negative.

\section{METHODOLOGY}

The DF and PP unit root test statistics are used to examine the stationarity of the data. The J cointegration method is used to examine the long-run relationship among variables in a system. The J cointegration method proposes two likelihood ratio tests to test the number of cointegrating vectors in a system, namely the maximum eigenvalue $\left(\lambda_{M a x}\right)$ and trace $\left(\lambda_{\text {Trace }}\right)$ statistics, which are respectively computed as:

$$
\lambda_{\text {Max }}=-T \ln \left(1-\lambda_{r+1}\right)
$$




$$
\lambda_{\text {Trace }}=-T \sum_{i=r+1}^{p} \ln \left(1-\lambda_{i}\right)
$$

where $T$ is the sample size, $\ln$ is the logarithm, and $\lambda_{\mathrm{i}}$ is the eigenvalue. The $\lambda_{\text {Max }}$ test statistic tests the null hypothesis $\left(\mathrm{H}_{0}\right)$ of $\mathrm{r}$ cointegrating vectors against the alternative hypothesis $\left(\mathrm{H}_{\mathrm{a}}\right)$ that there are $\{\mathrm{r}+1\}$ cointegrating vectors in a system. The $\lambda_{\text {Trace }}$ test statistic tests the $\mathrm{H}_{0}$ that has at most $r$ cointegrating vectors in a system, that is, the number of cointegrating vectors is less than or equal to $r$. The critical values for the $\lambda_{\text {Max }}$ and $\lambda_{\text {Trace }}$ test statistics are tabulated in Pesaran, Shin, and Smith (2000). The distribution of the statistics depends upon the number of non-stationary components under the null hypothesis and whether or not a constant is included in the cointegrating vector.

In the Granger (1969) sense of a variable, $X$ causes another variable $Y$ if the current value of $Y$ can better be predicted by using the past values of $X$. When the series are cointegrated, the testing of Granger causality shall be in the vector error correction (VEC) models. ${ }^{3,4,5}$

$$
\begin{aligned}
& \Delta \log R E R_{t}=\beta_{10}+\sum_{i=1}^{a} \beta_{11 i} \Delta \log T O T_{t-i}+\sum_{i=1}^{a} \beta_{12 i} \Delta \log R D_{t-i}+\sum_{i=1}^{a} \beta_{13 i} \Delta \log R E R_{t-i}+\beta_{14} E C_{t-1}+u_{1, t} \\
& \Delta \log T O T_{t}=\beta_{20}+\sum_{i=1}^{a} \beta_{21 i} \Delta \log T O T_{t-i}+\sum_{i=1}^{a} \beta_{22 i} \Delta \log R D_{t-i}+\sum_{i=1}^{a} \beta_{23 i} \Delta \log R E R_{t-i}+\beta_{24} E C_{t-1}+u_{2, t} \\
& \Delta \log R D_{t}=\beta_{30}+\sum_{i=1}^{a} \beta_{31 i} \Delta \log T O T_{t-i}+\sum_{i=1}^{a} \beta_{32 i} \Delta \log R D_{t-i}+\sum_{i=1}^{a} \beta_{33 i} \Delta \log R E R_{t-i}+\beta_{34} E C_{t-1}+u_{3, t}
\end{aligned}
$$

where $\log$ is the natural logarithm, $R E R_{t}$ is real exchange rate, $T O T_{t}$ is terms of trade, $R D_{t}$ is relative demand, $E C_{t-1}$ is the one period lagged of error correction term, and $u_{i, t}(\mathrm{i}=1,2,3)$ is a disturbance term. The one period lagged of error correction terms show that the short-run endogenous adjustment brings the system back to its long-run equilibrium. The joint test of lagged variables, that is $\Delta \log R E R_{t^{\prime}} \Delta \log T O T_{t^{\prime}}$ and $\Delta \log R D_{t^{\prime}}$ by mean of the F-statistic (Wald statistic), is significantly different from zero, which implies the presence of Granger causality. For example, if the joint test of lagged variables of $\Delta \log \mathrm{TOT}_{t}$ in equation (3) is significantly 
different from zero, it implies that terms of trade Granger causes real exchange rate.

A theoretical explanation of the relationship between real exchange rate and terms of trade was given by Devereux and Connolly (1996). There are at least two channels that terms of trade can influence real exchange rate. The first channel is that a change in consumer preferences toward favour of domestic output, will increase terms of trade and appreciate real exchange rate of domestic economy. The second channel is terms of trade of domestic economy will increase due to a shift in foreign demand patterns toward its higher value of exports or a commodity price change that favours the production base of the domestic economy. This will appreciate the real exchange rate (Sager, 2006, p. 47).

Bagchi et al. (2004) estimated a long-run relationship of real exchange rate as a function of terms of trade and the expected real interest rate differential. Chen and Chen (2007) estimated real exchange rate as a function of real interest rate differential, productivity differential, and real oil price. It was argued that the Balassa-Samuelson hypothesis, which is expressed by relative demand in this study, is an empirically useful framework for investigating the long-run behaviour of real exchange rate for developing economies (Choudhri \& Khan, 2005, p.p. 405-406). Generally, an increase in terms of trade, relative demand, or the expected real interest rate would lead to an appreciation in real exchange rate.

The generalised forecast error variance decomposition and generalised impulse response function (Koop, et al. 1996; Pesaran \& Shin, 1998) are used to examine the relationship of variables in a system. The generalised forecast error variance decomposition identifies the proportion of forecast error variance in one variable caused by the innovations in other variables in a system. Therefore, the relative importance of a set of variables that affects a variance of another variable is identified. The generalised impulse response function traces the dynamic responses of a variable to innovations in other variables in a system. The generalised forecast error variance decomposition and generalised impulse response function (Koop et al., 1996; Pesaran \& Shin, 1998) solve the orthogonalised problem of the forecast error variance decomposition and impulse response function of Sims (1980). The problem is that the latter approaches are sensitive to the order of the variables in which they enter the vector autoregressive (VAR) system. 
Let $x_{\mathrm{t}}$ be an $m \times 1$ vector of jointly determined dependent variables, which are assumed to be a I(1) series, respectively. The infinite moving average representation of $\Delta x_{t}$ can be written as:

$$
\Delta x_{t}=\sum_{i=0}^{\infty} C_{i} \varepsilon_{t-i}+\sum_{i=0}^{\infty} C_{i} \Pi \Lambda w_{t-i}, t=1,2, \ldots, \mathrm{T}
$$

where $C_{i}$ is $m \times m$ coefficient matrices, $\Pi=\alpha^{\prime} \beta$ ( $\alpha$ and $\beta$ are $m \times m$ matrices of full rank $r$, that is, rank $(\Pi)=r), \Lambda$ is an $m \times g$ matrix of unknown coefficients and $w_{t}$ is an $q \times 1$ vector of deterministic and or exogenous variables.

The generalised impulse response function, which measures the effect of the shock to the $j$-th equation in (6) on $\Delta x_{t+n}$ can be written as:

$$
\Psi_{\Delta x_{j}(7)}(n)=\sigma_{j}^{-1 / 2} C_{n} \Sigma e_{j}, n=0,1,2, \ldots
$$

where $\sigma$ is standard error, $\Sigma$ is $m \times 1$ covariance matrix, and $e_{j}$ is an $m \times 1$ selection vector with unity as its $j$-th element and zero elsewhere.

The generalised forecast error variance decomposition is given by:

$$
\theta_{i j}(n)=\frac{\sigma_{i}^{-1} \Sigma_{l=0}^{n}\left(e_{i}^{\prime} C_{l} \Sigma e_{j}\right)^{2}}{\sum_{l=0}^{n}\left(e_{i}^{\prime} C_{l} \Sigma C_{l}^{\prime} e_{i}\right)}, i, j=1, \ldots, m
$$

Generally, the sum of the generalised forecast error variance decomposition is not one, that is, $\sum_{j=1}^{m} \theta_{i j}(n) \neq 1$ as the non-zero covariance between the original (non-orthogonalised) shocks.

\section{DATA}

Real effective exchange rate $(2000=100)$, exchange rate, export price $(2000=100)$, import price $(2000=100)$, industrial production $(2000=100)$, manufacturing production $(2000=100)$, consumer price $(2000=100)$, and 
money market rate were obtained from International Financial Statistics, the International Monetary Fund (IFS, IMF). ${ }^{6}$ In this study, terms of trade $\left(\right.$ TOT $\left._{t}\right)$ is defined as $\left(\mathrm{P}_{x, t} / \mathrm{P}_{\mathrm{m}, \mathrm{t}}\right)$ 100, where $\mathrm{P}_{\mathrm{x}, \mathrm{t}}$ is export price and $\mathrm{P}_{\mathrm{m}, \mathrm{t}}$ is import price. It is also called commodity terms of trade. Relative demand is defined as $\left(Y_{d, t} / Y_{w, t}\right)$, where $Y_{d, t}$ is domestic demand and $Y_{w, t}$ is world demand. Domestic demand and world demand are expressed by domestic industrial production (or manufacturing production) and world industrial production, respectively. ${ }^{7}$ Relative real interest rate is defined as $\left(\mathrm{R}_{\mathrm{d}, \mathrm{t}} / \mathrm{R}_{\mathrm{w}, \mathrm{t}}\right) \times\left(C P I_{\mathrm{d}, \mathrm{t}} / \mathrm{CPI} \mathrm{w}_{\mathrm{t}, \mathrm{t}}\right)$, where $\mathrm{R}_{\mathrm{d}, \mathrm{t}}$ is domestic money

market rate, $R_{w, t}$ is world money market rate, which is expressed by the US money market rate, $\mathrm{CPI}_{\mathrm{d}, \mathrm{t}}$ is domestic consumer price, and $\mathrm{CPI} \mathrm{w}_{\mathrm{w}, \mathrm{t}}$ is world consumer price, which is expressed by the US consumer price. The data are quarterly. More specifically, the sample periods are generally from 2006, quarter I 1975 to, quarter IV 1987 for Malaysia, from quarter I 1979 to, quarter II 2006 for Singapore, and from, quarter I 1993 to, quarter II 2006 for Thailand. The ranges of samples are subject to the availability of data especially the terms of trade data. Thus, this study had no main intention to compare the economies examined in the same time frame as the ranges of samples are not the same. All data were transformed into logarithms before estimation.

\section{EMPIRICAL RESULTS AND DISCUSSION}

The DF and PP unit root test statistics are reported in Table 2. The lag length used to compute the DF unit root test statistic is based on Akaike information criterion (AIC). For the PP unit root test statistic, the results that are reported are based on four truncation lags, which are used to compute the test statistic after considering truncation lags one, two, three, and four in computing the test statistic. Generally, results of the DF and PP unit root test statistics showed that all the variables are non-stationary in level but becoming stationary after taking the first differences, except terms of trade (no trend), relative demand (trend), and relative real interest rate (no trend, trend) of Malaysia, terms of trade (trend), relative demand (trend), and relative real interest rate (trend) of Singapore, and relative demand (no trend, trend) and relative real interest rate (no trend, trend) of Thailand. For terms of trade (no trend) of Malaysia, relative real interest rate (no trend, trend) of Malaysia and Thailand, and relative demand (no trend, trend) of Thailand, the DF unit root statistic showed no evidence of a unit root whilst the PP unit root statistic showed that there is a unit root. For relative demand (trend) of Malaysia, and relative demand (trend), terms of trade (trend), and relative real interest rate (trend) of Singapore, the DF and PP unit root statistics showed that they 
are a stationary series, respectively. Nonetheless, these series could be considered as a borderline case.

Table 2: The Dickey and Fuller (1979) (DF) and Phillips and Perron (1988) (PP) Unit Root Test Statistics

\begin{tabular}{|c|c|c|c|c|}
\hline & $\mathrm{t}_{\gamma}($ No Trend $)$ & $\mathrm{Z}\left(\mathrm{t}_{\gamma}\right)$ (No Trend) & $\mathrm{t}_{\gamma}($ Trend $)$ & $\mathrm{Z}\left(\mathrm{t}_{\gamma}\right)($ Trend) \\
\hline \multicolumn{5}{|l|}{ Malaysia } \\
\hline $\log R E R_{m, t}$ & $-0.9468(3)$ & $-1.2013(4)$ & $-2.9134(3)$ & $-2.3512(4)$ \\
\hline$\Delta \log R E R_{m, t}$ & $-5.6587^{* * *}(2)$ & $-7.4803^{* * *}(4)$ & $-5.6523^{* * *}(2)$ & $-7.4453^{* * *}(4)$ \\
\hline $\log T O T_{m, t}$ & $-3.3933^{* *}(1)$ & $-3.2916(4)$ & $-3.4415(1)$ & $-3.3282(4)$ \\
\hline$\Delta \log T O T_{m, t}$ & $-8.0242^{* * *}(0)$ & $-7.9996^{* * *}(4)$ & $-7.9692^{* * *}(0)$ & $-7.9419^{* * *}(4)$ \\
\hline $\log R D_{m, t}$ & $-0.6498(8)$ & $-0.6847(4)$ & $-3.5386^{* *}(8)$ & $-4.4358^{* * *}(4)$ \\
\hline$\Delta \log R D_{m, t}$ & $-3.7755^{* * *}(7)$ & $-13.7332^{* * *}(4)$ & $-3.7691^{* *}(7)$ & $-13.6760^{* * *}(4)$ \\
\hline $\log R R_{m, t}$ & $-4.1407^{* * *}(4)$ & $-2.9705(4)$ & $-4.9202^{* * *}(4)$ & $-3.2690(4)$ \\
\hline$\Delta \log R R_{m, t}$ & $-4.8831^{* * *}(4)$ & $-9.0849^{* * *}(4)$ & $-4.8639^{* * *}(4)$ & $-9.0504^{* * *}(4)$ \\
\hline \multicolumn{5}{|l|}{ Singapore } \\
\hline $\log R E R_{s, t}$ & $-2.6767(3)$ & $-3.2270(4)$ & $-2.6666(3)$ & $-2.9960(4)$ \\
\hline$\Delta \log R E R_{s, t}$ & $-7.9037^{* * *}(0)$ & $-8.0291^{* * *}(4)$ & $-7.8909^{* * *}(0)$ & $-8.0343^{* * *}(4)$ \\
\hline $\log \mathrm{TOT}_{s, t}$ & $1.1753(1)$ & $1.0709(4)$ & $-2.7392^{* * *}(4)$ & $-4.1629^{* *}(4)$ \\
\hline$\Delta \log \mathrm{TOT}_{s, t}$ & $-10.8769^{* * *}(0)$ & $-10.8623^{* * *}(4)$ & $-11.3014^{* * *}(0)$ & $-11.2733^{* * *}(4)$ \\
\hline $\log R D_{s, t}$ & $-1.3366(8)$ & $-1.8197(4)$ & $-3.6988^{* *}(8)$ & $-3.9791^{* *}(4)$ \\
\hline$\Delta \log R D_{s, t}$ & $-3.3521^{* *}(7)$ & $-13.7332^{* * *}(4)$ & $-4.4574^{* * *}(6)$ & $-13.6760^{* * *}(4)$ \\
\hline $\log R R_{s, t}$ & $-2.8291(0)$ & $-2.7026(4)$ & $-4.5261^{* * *}(0)$ & $-4.6513^{* * *}(4)$ \\
\hline$\Delta \log R R_{s, t}$ & $-10.5270^{* * *}(1)$ & $-12.2597^{* * *}(4)$ & $-10.4874^{* * *}(1)$ & $-12.2075^{* * *}(4)$ \\
\hline \multicolumn{5}{|l|}{ Thailand } \\
\hline $\log R E R_{t, t}$ & $-0.4282(5)$ & $-0.5667(4)$ & $-2.5174(4)$ & $-2.4180(4)$ \\
\hline$\Delta \log R E R_{t, t}$ & $-6.0467^{* * *}(4)$ & $-8.5300^{* * *}(4)$ & $-6.0560^{* * *}(4)$ & $-8.5091^{* * *}(4)$ \\
\hline $\log \mathrm{TOT}_{t, t}$ & $-2.3472(0)$ & $-2.4040(4)$ & $-3.2483(0)$ & $-3.4024(4)$ \\
\hline$\Delta \log \mathrm{TOT}_{t, t}$ & $-13.5824^{* * *}(0)$ & $-13.5916^{* * *}(4)$ & $-13.5479^{* * *}(0)$ & $-13.5563^{* * *}(4)$ \\
\hline $\log R D_{t, t}$ & $-1.5128(5)$ & $-1.5767(4)$ & $-1.8295(5)$ & $-1.7799(4)$ \\
\hline$\Delta \log R D_{t, t}$ & $-2.4137(4)$ & $-6.8765^{* * *}(4)$ & $-2.4242(4)$ & $-6.7882^{* * *}(4)$ \\
\hline $\log R R_{t, t}$ & $-3.4595^{* *}(7)$ & $-2.9419(4)$ & $-3.53664^{* *}(7)$ & $-2.9593(4)$ \\
\hline$\Delta \log R R_{t, t}$ & $-5.2718^{* * *}(4)$ & $-9.6444^{* * *}(4)$ & $-5.2477^{* * *}(4)$ & $-9.6043^{* * *}(4)$ \\
\hline
\end{tabular}

Notes: $\mathrm{t}$ is the $\mathrm{DF}$ t-statistic. $\mathrm{Z}(\mathrm{t})$ is the PP $\mathrm{t}$-statistic. RER is real exchange rate of $i(i=$ Malaysia $(m)$, Singapore (s), Thailand $(t)$ ). Similarly, TOT is terms of trade of $i . R D$ is relative demand of $i . R R$ is relative real interest rate of $i$. No Trend denotes the DF and PP $t$-statistics are estimated based on the models including an intercept. Trend denotes the DF and PP t-statistics are estimated based on the models including an intercept and a time trend. Values in parentheses are the lag length used in the estimation of the DF or PP unit root test statistic. Critical values can be obtained from MacKinnon (1996). ${ }^{* * *}\left({ }^{* *}\right)$ denotes significance at the $1 \%(5 \%)$ level. 
The $\lambda_{\text {Max }}$ and $\lambda_{\text {Trace }}$ test statistics are reported in Table 3. The $\lambda_{\text {Max }}$ and $\lambda_{\text {Trace }}$ test statistics are computed with unrestricted intercepts and no trends. The lag length used in the estimations of the $\lambda_{\text {Max }}$ and $\lambda_{\text {Trace }}$ test statistics are based on AIC. For Thailand, a dummy variable, that is one for quarter one 1997 to quarter four 1998, and the rest are zero, is included in the estimation as an additional explanatory variable to capture the influence of the Asian financial crisis, 1997-1998. For the three-variable and four-variable cases, the results of the $\lambda_{\text {Max }}$ and $\lambda_{\text {Trace }}$ test statistics showed that there is evidence of cointegration for Malaysia and Thailand. Conversely for Singapore, the results of the $\lambda_{\text {Max }}$ and $\lambda_{\text {Trace }}$ test statistics showed that there is no evidence of cointegration in the threevariable or four-variable case. For the three-variable case, there is a longrun relationship among real exchange rate, terms of trade, and relative demand for Malaysia and Thailand. For the four-variable case, there is a long-run relationship among real exchange rate, terms of trade, relative demand, and relative real interest rate for Malaysia and Thailand. For the evidence of cointegration, the estimation of Granger causality shall be in the VEC models. On the other hand, the estimation of Granger causality shall be in the VAR models.

Table 3: The Johansen (1988) Likelihood Ratio Test Statistics

The Three-Variable Case

\begin{tabular}{lcccccccc}
\hline Model & \multicolumn{3}{c}{$\lambda_{\text {Max }}$ Test Statistic } & \multicolumn{5}{c}{$\lambda_{\text {Trace }}$ Test Statistic } \\
\hline $\mathrm{H}_{0}:$ & $\mathrm{r}=0$ & $\mathrm{r}<=1$ & $\mathrm{r}<=2$ & $\mathrm{r}<=3$ & $\mathrm{r}=0$ & $\mathrm{r}<=1$ & $\mathrm{r}<=2$ & $\mathrm{r}<=3$ \\
$\mathrm{H}:$ & $\mathrm{r}=1$ & $\mathrm{r}=2$ & $\mathrm{r}=3$ & $\mathrm{r}=4$ & $\mathrm{r} \geq 1$ & $\mathrm{r} \geq 2$ & $\mathrm{r}=23$ & $\mathrm{r}=4$ \\
\hline Malaysia & $29.49^{* *}$ & 9.04 & 0.001 & - & $38.53^{* *}$ & 9.04 & 0.001 & - \\
Singapore & 16.75 & 9.94 & 0.24 & - & 26.94 & 10.19 & 0.24 & - \\
Thailand & $69.99^{* *}$ & $25.30^{* *}$ & 14.74 & 3.68 & $113.72^{* *}$ & $43.72^{* *}$ & $18.42^{* *}$ & 3.68 \\
\hline c.v. & 21.12 & 14.88 & 8.07 & - & 31.54 & 17.86 & 8.07 & - \\
c.v. & 27.42 & 21.12 & 14.88 & 8.07 & 48.88 & 31.54 & 17.86 & 8.07 \\
\hline
\end{tabular}

The Four-Variable Case

\begin{tabular}{lcccccccccc}
\hline Model & \multicolumn{7}{c}{$\lambda_{\text {Max }}$ Test Statistic } & \multicolumn{7}{c}{$\lambda_{\text {Trace }}$ Test Statistic } \\
\hline $\mathrm{H}_{0}:$ & $\mathrm{r}=0$ & $\mathrm{r}<=1$ & $\mathrm{r}<=2$ & $\mathrm{r}<=3$ & $\mathrm{r}<=$ & $\mathrm{r}=0$ & $\mathrm{r}<=1$ & $\mathrm{r}<=2$ & $\mathrm{r}<=3$ & $\mathrm{r}<=4$ \\
$\mathrm{H}$ : & $\mathrm{r}=1$ & $\mathrm{r}=2$ & $\mathrm{r}=3$ & $\mathrm{r}=4$ & $\mathrm{r}=5$ & $\mathrm{r} \geq 1$ & $\mathrm{r} \geq 2$ & $\mathrm{r} \geq 3$ & $\mathrm{r} \geq 04$ & $\mathrm{r}=5$ \\
\hline Malaysia & $71.91^{* *}$ & $41.61^{* *}$ & 8.10 & 1.30 & - & $122.93^{* *}$ & 51.01 & 9.40 & 1.30 & - \\
Singapore & 22.26 & 15.92 & 6.87 & 1.08 & - & 46.14 & 23.88 & 7.96 & 1.08 & - \\
Thailand & $37.42^{* *}$ & 24.53 & 19.88 & 3.79 & 3.03 & $88.65^{* *}$ & $51.23^{* *}$ & 26.70 & 6.82 & 3.03 \\
\hline c.v. & 27.42 & 21.12 & 14.88 & 8.07 & - & 48.88 & 31.54 & 17.86 & 8.07 & - \\
c.v. & 33.634 & 27.42 & 21.12 & 14.88 & 8.07 & 70.49 & 48.88 & 31.54 & 17.86 & 8.07 \\
\hline
\end{tabular}

Notes: For the three-variable case, VAR $=8$ is used for Malaysia. For Singapore, VAR $=7$ is used. For Thailand, $\mathrm{VAR}=8$ is used. For the four-variable case, VAR $=8$ is used for Malaysia. For Singapore, VAR $=5$ is used. For Thailand, VAR $=3$ is used. c.v. denotes the $95 \%$ critical value. ${ }^{* *}$ denotes significance at the $95 \%$ critical value. 
The results of the Granger causality test are reported in Table 4. For no evidence of cointegration, the results of the Granger causality test in pairs of variables as well as causality in the VAR models are reported. For evidence of cointegration, the results of the Granger causality test in the VEC Models only are reported. The lag length used in the estimations of the Granger causality test is based on AIC. For Thailand, a dummy variable is included in the estimation to capture the influence of the Asian financial crisis. On the whole, the Granger causality test in pairs of variables showed that the $\mathrm{H}_{0}$ of no Granger causality is not rejected, except for that real exchange rate is found to Granger cause terms of trade of Singapore. However, when the test of causality is the VAR or VEC models, the $\mathrm{H}_{0}$ of no Granger causality is rejected in most cases. For the three-variable case, the Wald test statistic, which tests no Granger causality from real exchange rate to terms of trade, is not rejected, except for Thailand. Thus, terms of trade is predictable by real exchange rate in the system. For the four-variable case, no Granger causality is rejected for most cases. Generally, real exchange rate, terms of trade, relative demand, and relative real interest rate are predictable by other variables in the system, except for Singapore. Swift (2004) reported that the smalleconomy assumption of an economy is unlikely to hold. A change in real exchange rate will have a subsequent impact on terms of trade.

Table 4: The Results of the Granger Causality Test

The Three-Variable Case

\begin{tabular}{|c|c|c|c|c|}
\hline \multirow{2}{*}{$\frac{\mathrm{H}_{\mathrm{o}}}{\text { Singapore }}$} & & & \multicolumn{2}{|c|}{ Test Value } \\
\hline & & & & \\
\hline \multicolumn{2}{|c|}{$\Delta \log T O T_{t} \neq>\Delta \log R E R_{t}$} & & \multicolumn{2}{|c|}{0.0046} \\
\hline \multicolumn{3}{|c|}{$\Delta \log R E R_{t} \neq>\Delta \log \mathrm{TOT}_{t}$} & \multicolumn{2}{|c|}{$4.0293^{* *}$} \\
\hline \multicolumn{3}{|c|}{$\Delta \log R D_{t} \neq>\Delta \log R E R_{t}$} & \multicolumn{2}{|c|}{1.3927} \\
\hline \multicolumn{3}{|c|}{$\Delta \log R E R_{t} \neq>\Delta \log R D_{t}$} & \multicolumn{2}{|c|}{1.6130} \\
\hline \multicolumn{3}{|c|}{$\Delta \log R D_{t} \neq>\Delta \log \mathrm{TOT}_{t}$} & \multicolumn{2}{|c|}{1.3106} \\
\hline \multicolumn{3}{|c|}{$\Delta \log \mathrm{TOT}_{t} \neq>\Delta \log R D_{t}$} & \multicolumn{2}{|c|}{1.6130} \\
\hline & $E C_{t-1}$ & $\Delta \log \mathrm{TOT}_{t}$ & $\Delta \log R D_{t}$ & $\Delta \log R E R_{t}$ \\
\hline \multicolumn{5}{|l|}{ Malaysia } \\
\hline$\Delta \log R E R_{t}$ & $-1.9356^{*}$ & $25.8238^{* * *}$ & 11.5261 & - \\
\hline$\Delta \log \mathrm{TOT}_{t}$ & $-1.7620^{*}$ & - & $13.5149^{*}$ & 10.3922 \\
\hline$\Delta \log R D_{t}$ & 0.2775 & 10.8041 & - & 6.4526 \\
\hline
\end{tabular}


Table 4 (continued)

\begin{tabular}{lcccc}
\hline & $E C_{t-1}$ & $\Delta \log T O T_{t}$ & $\Delta \log R D_{t}$ & $\Delta \log R E R_{t}$ \\
\hline Singapore & \multicolumn{5}{c}{} \\
\hline$\Delta \log R E R_{t}$ & - & $15.6559^{* *}$ & $16.6551^{* *}$ & - \\
$\Delta \log T O T_{t}$ & - & - & 9.6842 & 7.4557 \\
$\Delta \log R D_{t}$ & - & 4.9624 & - & 7.0073 \\
\hline Thailand & & & & \\
\hline$\Delta \log R E R_{t}$ & $2.1862^{* *}$ & $14.9964^{*}$ & 3.3422 & - \\
$\Delta \log T O T_{t}$ & -1.4619 & - & $136.7875^{* * *}$ & $589.5196^{* * *}$ \\
$\Delta \log R D_{t}$ & $-1.7986^{*}$ & 8.7387 & - & $32.7734^{* * *}$ \\
\hline
\end{tabular}

The Four-Variable Case

Singapore

\begin{tabular}{|c|c|c|c|c|c|}
\hline \multicolumn{4}{|l|}{$\mathrm{H}_{\mathrm{o}}$} & \multicolumn{2}{|c|}{ Test Value } \\
\hline \multicolumn{2}{|c|}{$\Delta \log R R_{t} \neq>\Delta \log R E R_{t}$} & & & \multicolumn{2}{|c|}{2.4176} \\
\hline \multirow{2}{*}{\multicolumn{2}{|c|}{$\begin{array}{l}\Delta \log R E R_{t} \neq>\Delta \log R R_{t} \\
\Delta \log R R_{t} \neq>\Delta \log \mathrm{TOT}_{t}\end{array}$}} & & & \multicolumn{2}{|c|}{0.0625} \\
\hline & & & & \multicolumn{2}{|c|}{0.0047} \\
\hline \multicolumn{2}{|c|}{$\Delta \log \mathrm{TOT}_{t} \neq>\Delta \log R R_{t}$} & & & \multicolumn{2}{|c|}{0.1210} \\
\hline \multicolumn{3}{|c|}{$\Delta \log R R_{t} \neq>\Delta \log R D_{t}$} & & \multicolumn{2}{|c|}{0.9809} \\
\hline \multicolumn{3}{|c|}{$\Delta \log R D_{t} \neq>\Delta \log R R_{t}$} & & \multicolumn{2}{|c|}{1.2124} \\
\hline & $E C_{t-1}$ & $\Delta \log \mathrm{TOT}_{t}$ & $\Delta \log R D_{t}$ & $\Delta \log R R_{t}$ & $\Delta \log R E R_{t}$ \\
\hline \multicolumn{6}{|l|}{ Malaysia } \\
\hline$\Delta \log R E R_{t}$ & 0.1556 & $18.3623^{* *}$ & $41.3043^{* * *}$ & 10.2755 & - \\
\hline$\Delta \log \mathrm{TOT}_{t}$ & -1.7903 & - & 5.6429 & 5.3376 & 8.9482 \\
\hline$\Delta \log R D_{t}$ & 0.2571 & 12.0826 & - & 7.0561 & 9.7872 \\
\hline$\Delta \log R R_{t}$ & $2.9574^{* *}$ & $34.9371^{* * *}$ & $39.1222^{* * *}$ & - & $41.8675^{* * *}$ \\
\hline \multicolumn{6}{|l|}{ Singapore } \\
\hline$\Delta \log R E R_{t}$ & - & 1.8736 & $10.0477^{*}$ & 1.1352 & - \\
\hline$\Delta \log \mathrm{TOT}_{t}$ & - & - & 5.1544 & 2.3053 & 7.6990 \\
\hline$\Delta \log R D_{t}$ & - & 4.6940 & - & 5.3082 & 0.9651 \\
\hline$\Delta \log R R_{t}$ & - & 3.6271 & 4.3309 & - & 0.8354 \\
\hline \multicolumn{6}{|l|}{ Thailand } \\
\hline$\Delta \log R E R_{t}$ & 0.3571 & $16.4244^{* *}$ & 4.3749 & $27.2104^{* * *}$ & - \\
\hline$\Delta \log \mathrm{TOT}_{t}$ & -1.1729 & - & $68.9794^{* * *}$ & $117.1390^{* * *}$ & 4.9548 \\
\hline$\Delta \log R D_{t}$ & -0.4980 & $14.2146^{*}$ & - & $16.7721^{* *}$ & 3.6817 \\
\hline$\Delta \log R R_{t}$ & 0.0959 & $152.6217^{* * *}$ & $78.1693^{* * *}$ & - & 9.7066 \\
\hline
\end{tabular}

Notes: $\neq>$ denotes no Granger causality. ${ }^{* * *}\left({ }^{* *},{ }^{*}\right)$ denotes significance at the $1 \%(5 \%, 10 \%)$ level.

242 IJMS 16 (1), 229-259 (2009) 
The results of the generalised forecast error variance decomposition are reported in Tables 5 to 10. The results of the generalised forecast error variance decomposition reported are based on the 1 to 10, 15, and 20 horizon periods. The lag length used in the estimations of the generalised forecast error variance decomposition is based on AIC. For Thailand, a dummy variable is included in the estimation to capture the influence of the Asian financial crisis. For the three-variable case, the results showed that the contribution of terms of trade to real exchange rate is mixed. For Malaysia, the contribution of terms of trade to real exchange rate is smaller than the contribution of relative demand over the horizon periods from 0 to 4 , and the contribution of terms of trade to real exchange rate is greater than the contribution of relative demand over the horizon periods from 5 to 20. For Singapore, the contribution of terms of trade to real exchange rate is greater than the contribution of relative demand over the horizon periods from 0 to 1 , and the contribution of terms of trade to real exchange rate is smaller than the contribution of relative demand over the horizon periods from 2 to 20. It is about the same pattern for Thailand (Table 5). For terms of trade of Malaysia or Singapore, the results showed that terms of trade is explained mainly by its own innovation. The contributions of relative demand and real exchange rate are relatively small but vary across economies. For Thailand, the contributions of real exchange rate and relative demand on terms of trade are relatively high (Table 6). Relative demand of Malaysia, Singapore, or Thailand is explained mainly by its own innovation. The contributions of terms of trade and real exchange rate are relatively small but vary across economies (Table 7).

Table 5: The Generalised Forecast Error Variance Decomposition - Real Exchange Rate

The Three-Variable Case

\begin{tabular}{ccccccc}
\hline & \multicolumn{3}{c}{ Malaysia } & \multicolumn{3}{c}{ Singapore } \\
\hline \multirow{2}{*}{ Horizon } & $\Delta \log$ & $\Delta \log$ & $\Delta \log$ & $\Delta \log$ & $\Delta \log$ & $\Delta \log$ \\
& $R E R_{m, t}$ & $T O T_{m, t}$ & $R D_{m, t}$ & $R E R_{s, t}$ & $T O T_{s, t}$ & $R D_{s, t}$ \\
\hline 0 & 1.0000 & 0.0249 & 0.1173 & 1.0000 & 0.0273 & 0.0005 \\
1 & 0.9930 & 0.0383 & 0.1147 & 0.9956 & 0.0385 & 0.0011 \\
2 & 0.9116 & 0.0985 & 0.2032 & 0.9414 & 0.0355 & 0.0569 \\
3 & 0.9011 & 0.1164 & 0.2320 & 0.9424 & 0.0363 & 0.0557 \\
4 & 0.8420 & 0.1642 & 0.2261 & 0.9291 & 0.0419 & 0.0595 \\
5 & 0.6909 & 0.3070 & 0.2428 & 0.9247 & 0.0419 & 0.0637 \\
6 & 0.6715 & 0.3211 & 0.2331 & 0.9095 & 0.0451 & 0.0754 \\
7 & 0.6602 & 0.3142 & 0.2459 & 0.9085 & 0.0455 & 0.0761 \\
\hline
\end{tabular}




\begin{tabular}{|c|c|c|c|c|c|c|}
\hline \multicolumn{7}{|c|}{ Table 5 (continued) } \\
\hline Horizon & $\begin{array}{l}\Delta \log \\
R E R_{m, t}\end{array}$ & $\begin{array}{l}\Delta \log \\
\mathrm{TOT}_{m, t}\end{array}$ & $\begin{array}{l}\Delta \log \\
R D_{m, t}\end{array}$ & $\begin{array}{l}\Delta \log \\
R E R_{s, t}\end{array}$ & $\begin{array}{l}\Delta \log \\
\mathrm{TOT}_{s, t}\end{array}$ & $\begin{array}{l}\Delta \log \\
R D_{s, t}\end{array}$ \\
\hline 8 & 0.6485 & 0.3257 & 0.2451 & 0.9037 & 0.0485 & 0.0781 \\
\hline 9 & 0.6486 & 0.3262 & 0.2440 & 0.9019 & 0.0491 & 0.0795 \\
\hline 10 & 0.6427 & 0.3229 & 0.2485 & 0.8980 & 0.0510 & 0.0818 \\
\hline 15 & 0.5519 & 0.3878 & 0.2289 & 0.8959 & 0.0527 & 0.0827 \\
\hline 20 & 0.5396 & 0.3905 & 0.2260 & 0.8957 & 0.0529 & 0.0827 \\
\hline \multicolumn{7}{|c|}{ Thailand } \\
\hline \multirow{2}{*}{\multicolumn{2}{|c|}{ Horizon }} & $\Delta \log$ & & $\Delta \log$ & \multirow{2}{*}{\multicolumn{2}{|c|}{$\begin{array}{l}\Delta \log \\
R D_{t, t}\end{array}$}} \\
\hline & & $R E R_{t, t}$ & & $\mathrm{TOT}_{t, t}$ & & \\
\hline \multicolumn{2}{|l|}{0} & 1.0000 & & 0.0331 & \multicolumn{2}{|r|}{0.0083} \\
\hline \multicolumn{2}{|l|}{1} & 0.9104 & & 0.0352 & \multicolumn{2}{|r|}{0.0899} \\
\hline \multicolumn{2}{|l|}{2} & 0.7979 & & 0.0310 & \multicolumn{2}{|r|}{0.1980} \\
\hline \multicolumn{2}{|l|}{3} & 0.8052 & & 0.0311 & \multicolumn{2}{|r|}{0.2027} \\
\hline \multicolumn{2}{|l|}{4} & 0.8066 & & 0.0400 & \multicolumn{2}{|r|}{0.1999} \\
\hline \multicolumn{2}{|l|}{5} & 0.7813 & & 0.0475 & \multicolumn{2}{|r|}{0.2170} \\
\hline \multicolumn{2}{|l|}{6} & 0.7839 & & 0.0450 & \multicolumn{2}{|r|}{0.2070} \\
\hline \multicolumn{2}{|l|}{7} & 0.7817 & & 0.0463 & \multicolumn{2}{|r|}{0.2057} \\
\hline \multicolumn{2}{|l|}{8} & 0.7670 & & 0.0489 & \multicolumn{2}{|r|}{0.2181} \\
\hline \multicolumn{2}{|l|}{9} & 0.7271 & & 0.0453 & \multicolumn{2}{|r|}{0.2670} \\
\hline \multicolumn{2}{|l|}{10} & 0.7242 & & 0.0457 & \multicolumn{2}{|r|}{0.2644} \\
\hline \multicolumn{2}{|l|}{15} & 0.7057 & & 0.0509 & \multicolumn{2}{|r|}{0.2671} \\
\hline \multicolumn{2}{|l|}{20} & 0.6739 & & 0.0544 & & 0.2829 \\
\hline
\end{tabular}

The Four-Variable Case

\begin{tabular}{ccccccccc}
\hline \multicolumn{1}{c}{ Malaysia } & \multicolumn{5}{c}{ Singapore } \\
\hline \multirow{2}{*}{ Horizon } & $\Delta \log$ & $\Delta \log$ & $\Delta \log$ & $\Delta \log$ & $\Delta \log$ & $\Delta \log$ & $\Delta \log$ & $\Delta \log$ \\
& $R E R_{m, t}$ & $T O T_{m, t}$ & $R D_{m, t}$ & $R R_{m, t}$ & $R E R_{s, t}$ & $T O T_{s, t}$ & $R D_{s, t}$ & $R R_{s, t}$ \\
\hline 0 & 1.0000 & 0.0001 & 0.0213 & 0.1211 & 1.0000 & 0.0291 & 0.0032 & 0.0027 \\
1 & 0.9042 & 0.0001 & 0.0255 & 0.1459 & 0.9900 & 0.0299 & 0.0037 & 0.0169 \\
2 & 0.7911 & 0.0930 & 0.1124 & 0.1581 & 0.9880 & 0.0298 & 0.0044 & 0.0194 \\
3 & 0.7927 & 0.0942 & 0.0994 & 0.1351 & 0.9876 & 0.0297 & 0.0046 & 0.0199 \\
4 & 0.7159 & 0.1406 & 0.1634 & 0.1218 & 0.9876 & 0.0297 & 0.0046 & 0.0200 \\
5 & 0.5851 & 0.2781 & 0.2259 & 0.1148 & 0.9876 & 0.0297 & 0.0046 & 0.0200 \\
6 & 0.5282 & 0.3467 & 0.2256 & 0.1330 & 0.9875 & 0.0297 & 0.0046 & 0.0200 \\
7 & 0.5081 & 0.3300 & 0.2363 & 0.1518 & 0.9875 & 0.0297 & 0.0046 & 0.0200 \\
8 & 0.4849 & 0.3655 & 0.2242 & 0.2161 & 0.9875 & 0.0297 & 0.0046 & 0.0200 \\
9 & 0.4634 & 0.3936 & 0.2350 & 0.2368 & 0.9875 & 0.0297 & 0.0046 & 0.0200 \\
10 & 0.4594 & 0.3955 & 0.2342 & 0.2322 & 0.9875 & 0.0297 & 0.0046 & 0.0200 \\
15 & 0.3320 & 0.5638 & 0.2407 & 0.2796 & 0.9875 & 0.0297 & 0.0046 & 0.0200 \\
20 & 0.3299 & 0.5514 & 0.2327 & 0.2706 & 0.9875 & 0.0297 & 0.0046 & 0.0200 \\
\hline
\end{tabular}

244 IJMS 16 (1), 229-259 (2009) 
Table 5 (continued)

\begin{tabular}{ccccc}
\hline \multicolumn{5}{c}{ Thailand } \\
\hline \multirow{2}{*}{ Horizon } & $\Delta \log$ & $\Delta \log$ & $\Delta \log$ & $\Delta \log$ \\
& $R E R_{t, t}$ & $T O T_{t, t}$ & $R D_{t, t}$ & $R R_{t, t}$ \\
\hline 0 & 1.0000 & 0.0091 & 0.1010 & 0.2351 \\
1 & 0.9975 & 0.0097 & 0.0993 & 0.2377 \\
2 & 0.9269 & 0.0734 & 0.1049 & 0.2252 \\
3 & 0.9107 & 0.0433 & 0.1209 & 0.1488 \\
4 & 0.9069 & 0.0404 & 0.1385 & 0.1576 \\
5 & 0.8211 & 0.1046 & 0.1282 & 0.1416 \\
6 & 0.7750 & 0.0786 & 0.1784 & 0.1066 \\
7 & 0.7365 & 0.1192 & 0.1685 & 0.1024 \\
8 & 0.6667 & 0.1638 & 0.1398 & 0.0862 \\
9 & 0.6703 & 0.1291 & 0.1723 & 0.0681 \\
10 & 0.6116 & 0.1760 & 0.1818 & 0.0648 \\
15 & 0.5083 & 0.1659 & 0.2167 & 0.0371 \\
20 & 0.4786 & 0.1659 & 0.2227 & 0.0171 \\
\hline
\end{tabular}

Table 6: The Generalised Forecast Error Variance Decomposition - Terms of Trade

The Three-Variable Case

\begin{tabular}{ccccccc}
\hline \multicolumn{3}{c}{ Malaysia } & \multicolumn{3}{c}{ Singapore } \\
\hline \multirow{2}{*}{ Horizon } & $\Delta \log$ & $\Delta \log$ & $\Delta \log$ & $\Delta \log$ & $\Delta \log$ & $\Delta \log$ \\
& $R E R_{m, t}$ & $T O T_{m, t}$ & $R D_{m, t}$ & $R E R_{s, t}$ & $T O T_{s, t}$ & $R D_{s, t}$ \\
\hline 0 & 0.0249 & 1.0000 & 0.1961 & 0.0149 & 1.0000 & 0.0031 \\
1 & 0.0251 & 0.9933 & 0.1991 & 0.0374 & 0.9586 & 0.0113 \\
2 & 0.1152 & 0.8866 & 0.1756 & 0.0372 & 0.9390 & 0.0308 \\
3 & 0.1301 & 0.8697 & 0.1722 & 0.0423 & 0.9231 & 0.0424 \\
4 & 0.1427 & 0.8395 & 0.1808 & 0.0683 & 0.8939 & 0.0510 \\
5 & 0.1437 & 0.8388 & 0.1808 & 0.0683 & 0.8847 & 0.0604 \\
6 & 0.1572 & 0.7945 & 0.2426 & 0.0660 & 0.8716 & 0.0733 \\
7 & 0.1776 & 0.7721 & 0.2351 & 0.0732 & 0.8634 & 0.0736 \\
8 & 0.1792 & 0.7708 & 0.2397 & 0.0758 & 0.8609 & 0.0739 \\
9 & 0.1709 & 0.7816 & 0.2459 & 0.0754 & 0.8553 & 0.0795 \\
10 & 0.1786 & 0.7679 & 0.2432 & 0.0792 & 0.8519 & 0.0799 \\
15 & 0.1784 & 0.7553 & 0.2459 & 0.0824 & 0.8466 & 0.0813 \\
20 & 0.1782 & 0.7498 & 0.2477 & 0.0826 & 0.8463 & 0.0815 \\
\hline
\end{tabular}


Table 6 (continued)

\begin{tabular}{cccc}
\hline & \multicolumn{3}{c}{ Thailand } \\
\hline \multirow{2}{*}{ Horizon } & $\Delta \log$ & $\Delta \log$ & $\Delta \log$ \\
& $R E R_{t, t}$ & $T O T_{t, t}$ & $R D_{t, t}$ \\
\hline 0 & 0.0331 & 1.0000 & 0.0076 \\
1 & 0.4613 & 0.4894 & 0.0055 \\
2 & 0.5822 & 0.2567 & 0.1845 \\
3 & 0.4230 & 0.2006 & 0.3853 \\
4 & 0.3972 & 0.1822 & 0.4204 \\
5 & 0.3897 & 0.1864 & 0.4250 \\
6 & 0.4814 & 0.1517 & 0.3721 \\
7 & 0.5251 & 0.1392 & 0.3100 \\
8 & 0.5255 & 0.1379 & 0.3124 \\
9 & 0.4965 & 0.1412 & 0.3272 \\
10 & 0.4560 & 0.1292 & 0.3891 \\
15 & 0.4928 & 0.1080 & 0.3566 \\
20 & 0.4868 & 0.1286 & 0.3165 \\
\hline
\end{tabular}

Table 7: The Generalised Forecast Error Variance Decomposition Relative Demand

The Three-Variable Case

\begin{tabular}{ccccccc}
\hline \multicolumn{3}{c}{ Malaysia } & \multicolumn{3}{c}{ Singapore } \\
\hline \multirow{2}{*}{ Horizon } & $\Delta \log$ & $\Delta \log$ & $\Delta \log$ & $\Delta \log$ & $\Delta \log$ & $\Delta \log$ \\
& $R E R_{m, t}$ & $T O T_{m, t}$ & $R D_{m, t}$ & $R E R_{s, t}$ & $T O T_{s, t}$ & $R D_{s, t}$ \\
\hline 0 & 0.1173 & 0.1961 & 1.0000 & 0.0066 & 0.0031 & 1.0000 \\
1 & 0.0951 & 0.2491 & 0.8071 & 0.0161 & 0.0250 & 0.9715 \\
2 & 0.2096 & 0.1618 & 0.7943 & 0.0256 & 0.0441 & 0.9448 \\
3 & 0.2033 & 0.1967 & 0.7494 & 0.0269 & 0.0434 & 0.9449 \\
4 & 0.2412 & 0.1653 & 0.7262 & 0.0317 & 0.0669 & 0.9205 \\
5 & 0.2358 & 0.1612 & 0.7325 & 0.0343 & 0.0741 & 0.9109 \\
6 & 0.2352 & 0.1759 & 0.7209 & 0.0339 & 0.0738 & 0.9109 \\
7 & 0.2317 & 0.1849 & 0.7079 & 0.0535 & 0.0778 & 0.8835 \\
8 & 0.2266 & 0.2439 & 0.7208 & 0.0537 & 0.0944 & 0.8690 \\
9 & 0.2237 & 0.2474 & 0.6903 & 0.0590 & 0.0933 & 0.8658 \\
10 & 0.2348 & 0.2598 & 0.7051 & 0.0584 & 0.0923 & 0.8675 \\
15 & 0.2412 & 0.2508 & 0.7202 & 0.0598 & 0.1003 & 0.8567 \\
20 & 0.2551 & 0.2477 & 0.7386 & 0.0593 & 0.1027 & 0.8548 \\
\hline
\end{tabular}

246 IJMS 16 (1), 229-259 (2009) 
Table 7 (continued)

\begin{tabular}{cccc}
\hline & & Thailand \\
\hline \multirow{2}{*}{ Horizon } & $\Delta \log$ & $\Delta \log$ & $\Delta \log$ \\
& $R E R_{t, t}$ & $T O T_{t, t}$ & $R D_{t, t}$ \\
\hline 0 & 0.0083 & 0.0076 & 1.0000 \\
1 & 0.0279 & 0.0233 & 0.9584 \\
2 & 0.0886 & 0.0179 & 0.9220 \\
3 & 0.1437 & 0.0200 & 0.8632 \\
4 & 0.2963 & 0.0187 & 0.7072 \\
5 & 0.2961 & 0.0197 & 0.7062 \\
6 & 0.2987 & 0.0207 & 0.6935 \\
7 & 0.3367 & 0.0227 & 0.6582 \\
8 & 0.3537 & 0.0201 & 0.6557 \\
9 & 0.3536 & 0.0212 & 0.6541 \\
10 & 0.3362 & 0.0199 & 0.6670 \\
15 & 0.3848 & 0.0236 & 0.6107 \\
20 & 0.4209 & 0.0228 & 0.5775 \\
\hline
\end{tabular}

For the four-variable case of Malaysia, the contribution of relative real interest rate to real exchange rate is greater than the contribution of relative demand or terms of trade over the horizon periods from 0 to 3 . The contribution of terms of trade to real exchange rate is greater than the contribution of relative demand over the horizon periods from 5 to 20. For Singapore, the contribution of terms of trade to exchange rate is greater than the contribution of relative demand or relative real interest rate, and the contribution of relative real interest rate to real exchange rate is greater than the contribution of relative demand, except at the horizon period 0 . For Thailand, the contribution of relative demand to exchange rate is greater than the contribution of relative real interest rate, except at the horizon periods from 0 to 5 , and the contribution of relative real interest rate to real exchange rate is greater than the contribution of terms of trade, except after the horizon period $6 .{ }^{8}$ For terms of trade, relative demand or relative real interest rate of Malaysia, Singapore, or Thailand, the results showed that it is explained mainly by its own innovation, except terms of trade and relative real interest rate of Thailand. The contributions of other variables in the system are relatively small and vary across economies (Table 8, Table 9, and Table 10). 
Table 8: The Generalised Forecast Error Variance Decomposition - Terms of Trade

The Four-Variable Case

\begin{tabular}{|c|c|c|c|c|c|c|c|c|}
\hline \multirow[b]{2}{*}{ Horizon } & \multicolumn{4}{|c|}{ Malaysia } & \multicolumn{4}{|c|}{ Singapore } \\
\hline & $\begin{array}{c}\Delta \log \\
R E R_{m, t}\end{array}$ & $\begin{array}{c}\Delta \log \\
T O T_{m, t}\end{array}$ & $\begin{array}{l}\Delta \log \\
R D_{m, t}\end{array}$ & $\begin{array}{l}\Delta \log \\
R R_{m, t}\end{array}$ & $\begin{array}{l}\Delta \log \\
R E R_{s, t}\end{array}$ & $\begin{array}{l}\Delta \log \\
T^{\prime} T_{s, t}\end{array}$ & $\begin{array}{l}\Delta \log \\
R D_{s, t}\end{array}$ & $\begin{array}{l}\Delta \log \\
R R_{s, t}\end{array}$ \\
\hline 0 & 0.0001 & 1.0000 & 0.3221 & 0.3972 & 0.0291 & 1.0000 & 0.0297 & 0.0012 \\
\hline 1 & 0.0130 & 0.9633 & 0.3318 & 0.3827 & 0.0515 & 0.9735 & 0.0297 & 0.0011 \\
\hline 2 & 0.0840 & 0.8745 & 0.3042 & 0.3474 & 0.0565 & 0.9681 & 0.0296 & 0.0019 \\
\hline 3 & 0.0852 & 0.8626 & 0.3172 & 0.3412 & 0.0576 & 0.9669 & 0.0296 & 0.0020 \\
\hline 4 & 0.0822 & 0.8365 & 0.3165 & 0.3336 & 0.0578 & 0.9667 & 0.0296 & 0.0021 \\
\hline 5 & 0.1217 & 0.7827 & 0.2959 & 0.3456 & 0.0579 & 0.9666 & 0.0296 & 0.0021 \\
\hline 6 & 0.1175 & 0.7677 & 0.3189 & 0.3460 & 0.0579 & 0.9666 & 0.0296 & 0.0021 \\
\hline 7 & 0.1158 & 0.7710 & 0.3196 & 0.3459 & 0.0579 & 0.9666 & 0.0296 & 0.0021 \\
\hline 8 & 0.1216 & 0.7582 & 0.3361 & 0.3313 & 0.0579 & 0.9666 & 0.0296 & 0.0021 \\
\hline 9 & 0.1169 & 0.7665 & 0.3485 & 0.3199 & 0.0579 & 0.9666 & 0.0296 & 0.0021 \\
\hline 10 & 0.1167 & 0.7589 & 0.3669 & 0.3087 & 0.0579 & 0.9666 & 0.0296 & 0.0021 \\
\hline 15 & 0.2192 & 0.6203 & 0.3365 & 0.3126 & 0.0579 & 0.9666 & 0.0296 & 0.0021 \\
\hline 20 & 0.2687 & 0.5649 & 0.2876 & 0.3837 & 0.0579 & 0.9666 & 0.0296 & 0.0021 \\
\hline \multicolumn{9}{|c|}{ Thailand } \\
\hline \multicolumn{2}{|c|}{ Horizon } & \multicolumn{2}{|l|}{$\begin{array}{l}\Delta \log \\
R E R_{t, t}\end{array}$} & \multicolumn{2}{|l|}{$\begin{array}{l}\Delta \log \\
T_{O T T_{t, t}}\end{array}$} & $\begin{array}{l}\Delta \log \\
R D_{t, t}\end{array}$ & \multicolumn{2}{|r|}{$\begin{array}{c}\Delta \log \\
R R_{t, t}\end{array}$} \\
\hline \multicolumn{2}{|l|}{0} & \multicolumn{2}{|l|}{0.0091} & \multicolumn{2}{|l|}{1.0000} & 0.0269 & \multicolumn{2}{|r|}{0.0181} \\
\hline \multicolumn{2}{|l|}{1} & \multicolumn{2}{|l|}{0.6263} & 0.3335 & \multicolumn{2}{|r|}{0.0252} & \multicolumn{2}{|r|}{0.1849} \\
\hline \multicolumn{2}{|l|}{2} & \multicolumn{2}{|c|}{0.5419} & 0.3130 & \multicolumn{2}{|r|}{0.0816} & \multicolumn{2}{|r|}{0.1539} \\
\hline \multicolumn{2}{|l|}{3} & \multicolumn{2}{|c|}{0.4298} & 0.2243 & \multicolumn{2}{|r|}{0.3473} & \multicolumn{2}{|r|}{0.1240} \\
\hline \multicolumn{2}{|l|}{4} & \multicolumn{2}{|l|}{0.4134} & 0.2163 & \multicolumn{2}{|r|}{0.3380} & \multicolumn{2}{|r|}{0.1495} \\
\hline 5 & & 0.3817 & & 0.2004 & & 0.3982 & & 0.1389 \\
\hline 6 & & 0.4602 & & 0.1724 & & 0.3039 & & 0.1491 \\
\hline 7 & & 0.5269 & & 0.1281 & & 0.3559 & & 0.1427 \\
\hline 8 & & 0.5361 & & 0.1194 & & 0.3287 & & 0.1356 \\
\hline 9 & & 0.5049 & & 0.1193 & & 0.3260 & & 0.1502 \\
\hline 10 & & 0.5544 & & 0.1002 & & 0.3080 & & 0.1241 \\
\hline 15 & & 0.3983 & & 0.1859 & & 0.3441 & & 0.0852 \\
\hline 20 & & 0.3903 & & 0.2028 & & 0.2994 & & 0.0486 \\
\hline
\end{tabular}


Table 9: The Generalised Forecast Error Variance Decomposition Relative Demand

The Four-Variable Case

\begin{tabular}{ccccccccc}
\hline \multicolumn{1}{c}{ Malaysia } & \multicolumn{5}{c}{ Singapore } \\
\hline \multirow{2}{*}{ Horizon } & $\Delta \log$ & $\Delta \log$ & $\Delta \log$ & $\Delta \log$ & $\Delta \log$ & $\Delta \log$ & $\Delta \log$ & $\Delta \log$ \\
& $R E R_{m, t}$ & $T O T_{m, t}$ & $R D_{m, t}$ & $R R_{m, t}$ & $R E R_{s, t}$ & $T O T_{s, t}$ & $R D_{s, t}$ & $R R_{s, t}$ \\
\hline 0 & 0.0213 & 0.3221 & 1.0000 & 0.0118 & 0.0032 & 0.0297 & 1.0000 & 0.0152 \\
1 & 0.0185 & 0.3097 & 0.7511 & 0.0165 & 0.0237 & 0.0454 & 0.9489 & 0.0360 \\
2 & 0.0389 & 0.2448 & 0.7286 & 0.0672 & 0.0298 & 0.0451 & 0.9430 & 0.0361 \\
3 & 0.0338 & 0.2196 & 0.6312 & 0.0872 & 0.0309 & 0.0451 & 0.9419 & 0.0362 \\
4 & 0.0476 & 0.2721 & 0.5696 & 0.1250 & 0.0311 & 0.0451 & 0.9417 & 0.0362 \\
5 & 0.0473 & 0.2736 & 0.5118 & 0.1931 & 0.0311 & 0.0451 & 0.9416 & 0.0362 \\
6 & 0.1999 & 0.2298 & 0.4944 & 0.1585 & 0.0311 & 0.0451 & 0.9416 & 0.0362 \\
7 & 0.2886 & 0.2061 & 0.4369 & 0.1653 & 0.0311 & 0.0451 & 0.9416 & 0.0362 \\
8 & 0.3047 & 0.2154 & 0.4160 & 0.1616 & 0.0311 & 0.0451 & 0.9416 & 0.0362 \\
9 & 0.3233 & 0.2013 & 0.4039 & 0.1816 & 0.0311 & 0.0451 & 0.9416 & 0.0362 \\
10 & 0.2775 & 0.2415 & 0.3480 & 0.2989 & 0.0311 & 0.0451 & 0.9416 & 0.0362 \\
15 & 0.3719 & 0.2098 & 0.2917 & 0.3092 & 0.0311 & 0.0451 & 0.9416 & 0.0362 \\
20 & 0.3787 & 0.2128 & 0.2314 & 0.4106 & 0.0311 & 0.0451 & 0.9416 & 0.0362 \\
\hline
\end{tabular}

Thailand

\begin{tabular}{ccccc}
\hline Horizon & $\Delta \log$ & $\Delta \log$ & $\Delta \log$ & $\Delta \log$ \\
& $R E R_{t, t}$ & $T O T_{t, t}$ & $R D_{t, t}$ & $R R_{t, t}$ \\
\hline 0 & 0.1010 & 0.0269 & 1.0000 & 0.0654 \\
1 & 0.1042 & 0.0294 & 0.9851 & 0.0640 \\
2 & 0.1027 & 0.0279 & 0.9271 & 0.0596 \\
3 & 0.1059 & 0.0458 & 0.8895 & 0.0563 \\
4 & 0.2555 & 0.0412 & 0.7540 & 0.0693 \\
5 & 0.2539 & 0.0580 & 0.7117 & 0.0736 \\
6 & 0.2401 & 0.0535 & 0.6815 & 0.0970 \\
7 & 0.3138 & 0.0715 & 0.6509 & 0.0813 \\
8 & 0.2141 & 0.1112 & 0.6692 & 0.0646 \\
9 & 0.2310 & 0.1066 & 0.6501 & 0.0613 \\
10 & 0.2180 & 0.0980 & 0.6950 & 0.0580 \\
15 & 0.2979 & 0.1211 & 0.5742 & 0.0386 \\
20 & 0.3239 & 0.1474 & 0.4600 & 0.0200 \\
\hline
\end{tabular}

IJMS 16 (1), 229-259 (2009) 249 
Table 10: The Generalised Forecast Error Variance Decomposition Relative Real Interest Rate

The Four-Variable Case

\begin{tabular}{|c|c|c|c|c|c|c|c|c|}
\hline \multicolumn{6}{|c|}{ Malaysia } & \multicolumn{3}{|c|}{ Singapore } \\
\hline Horizon & $\begin{array}{l}\Delta \log \\
R E R_{m, t}\end{array}$ & $\begin{array}{l}\Delta \log \\
T O T_{m, t}\end{array}$ & $\begin{array}{l}\Delta \log \\
R D_{m, t}\end{array}$ & $\begin{array}{l}\Delta \log \\
R R_{m, t}\end{array}$ & $\begin{array}{l}\Delta \log \\
R E R_{s, t}\end{array}$ & $\begin{array}{l}\Delta \log \\
\text { TOT }_{s, t}\end{array}$ & $\begin{array}{l}\Delta \log \\
R D_{s, t}\end{array}$ & $\begin{array}{l}\Delta \log \\
R R_{s, t}\end{array}$ \\
\hline 0 & 0.1211 & 0.3972 & 0.0118 & 1.0000 & 0.0027 & 0.0012 & 0.0152 & 1.0000 \\
\hline 1 & 0.0711 & 0.6231 & 0.0969 & 0.8463 & 0.0099 & 0.0021 & 0.0378 & 0.9719 \\
\hline 2 & 0.2431 & 0.4838 & 0.0835 & 0.6450 & 0.0101 & 0.0022 & 0.0378 & 0.9715 \\
\hline 3 & 0.2959 & 0.4278 & 0.0997 & 0.6128 & 0.0101 & 0.0022 & 0.0378 & 0.9715 \\
\hline 4 & 0.3384 & 0.4084 & 0.0959 & 0.5988 & 0.0101 & 0.0022 & 0.0378 & 0.9715 \\
\hline 5 & 0.3474 & 0.3986 & 0.1032 & 0.5595 & 0.0101 & 0.0022 & 0.0378 & 0.9715 \\
\hline 6 & 0.5426 & 0.2572 & 0.1456 & 0.3769 & 0.0101 & 0.0022 & 0.0378 & 0.9715 \\
\hline 7 & 0.4694 & 0.3514 & 0.1695 & 0.4305 & 0.0101 & 0.0022 & 0.0378 & 0.9715 \\
\hline 8 & 0.4352 & 0.3634 & 0.2122 & 0.4277 & 0.0101 & 0.0022 & 0.0378 & 0.9715 \\
\hline 9 & 0.4212 & 0.3477 & 0.2216 & 0.4099 & 0.0101 & 0.0022 & 0.0378 & 0.9715 \\
\hline 10 & 0.4140 & 0.3316 & 0.2213 & 0.4235 & 0.0101 & 0.0022 & 0.0378 & 0.9715 \\
\hline 15 & 0.3602 & 0.4044 & 0.2635 & 0.4211 & 0.0101 & 0.0022 & 0.0378 & 0.9715 \\
\hline 20 & 0.3358 & 0.3728 & 0.2251 & 0.4989 & 0.0101 & 0.0022 & 0.0378 & 0.9715 \\
\hline \multicolumn{9}{|c|}{ Thailand } \\
\hline \multicolumn{2}{|c|}{ Horizon } & \multicolumn{2}{|l|}{$\begin{array}{l}\Delta \log \\
R E R_{t, t}\end{array}$} & $\begin{array}{l}\Delta \log \\
T_{O T}\end{array}$ & \multicolumn{2}{|r|}{$\begin{array}{l}\Delta \log \\
R D_{t, t}\end{array}$} & \multicolumn{2}{|c|}{$\begin{array}{l}\Delta \log \\
R R_{t, t}\end{array}$} \\
\hline \multicolumn{2}{|l|}{0} & \multicolumn{2}{|l|}{0.2351} & 0.0181 & \multicolumn{2}{|r|}{0.0654} & \multicolumn{2}{|c|}{1.0000} \\
\hline \multicolumn{2}{|l|}{1} & \multicolumn{2}{|l|}{0.4389} & 0.0091 & \multicolumn{2}{|r|}{0.3752} & \multicolumn{2}{|c|}{0.6225} \\
\hline \multicolumn{2}{|l|}{2} & \multicolumn{2}{|l|}{0.5055} & 0.0426 & \multicolumn{2}{|r|}{0.3156} & \multicolumn{2}{|c|}{0.5496} \\
\hline \multicolumn{2}{|l|}{3} & \multicolumn{2}{|l|}{0.4589} & 0.0332 & \multicolumn{2}{|r|}{0.4297} & \multicolumn{2}{|c|}{0.3415} \\
\hline \multicolumn{2}{|l|}{4} & \multicolumn{2}{|l|}{0.4451} & 0.0654 & \multicolumn{2}{|r|}{0.4116} & \multicolumn{2}{|c|}{0.3312} \\
\hline \multicolumn{2}{|l|}{5} & \multicolumn{2}{|l|}{0.4244} & 0.1098 & \multicolumn{2}{|r|}{0.3258} & & 502 \\
\hline 6 & & 0.5215 & & 0.0796 & & 0.2993 & & 747 \\
\hline 7 & & 0.4735 & & 0.1511 & & 0.2549 & & 726 \\
\hline 8 & & 0.5003 & & 0.1456 & & 0.2081 & & 396 \\
\hline 9 & & 0.4932 & & 0.1274 & & 0.2370 & & 219 \\
\hline 10 & & 0.4506 & & 0.1874 & & 0.2150 & & 979 \\
\hline 15 & & 0.4596 & & 0.1830 & & 0.2159 & & 437 \\
\hline 20 & & 0.5015 & & 0.1636 & & 0.1804 & 0.0 & 200 \\
\hline
\end{tabular}

The results of the generalised impulse response function are shown in Figures 1 to $4.9^{9}$ The results of the generalised impulse response function are plotted over the 20 horizon periods or equivalent to five 
year periods. For the three-variable case of Malaysia and Thailand, the responses of real exchange rate to one standard error shock in its own, terms of trade, or relative demand are positive and negative over the all horizon periods. However, the fluctuations of real exchange rate to one standard error shock in relative demand are higher than those of terms of trade. For Singapore, the responses of real exchange rate to one standard error shock on its own, terms of trade or relative demand are positive and negative over the horizon periods from 0 to 16 before dying out. Generally, the responses of terms of trade or relative demand to one standard error shock are about the same as in the responses of real exchange rate in the three-variable case. For the four-variable case, the responses of real exchange rate to one standard error shock on its own, terms of trade, or relative demand are about the same as in the threevariable case, except for Singapore. For Singapore, the responses of real exchange rate to one standard error shock on its own, terms of trade, relative demand, or relative real interest rate are relatively short and die out at the horizon period 6. Generally, one standard error shock in relative real interest rate will lead to the fluctuations of real exchange rate over time. The responses of terms of trade, relative demand, or relative real interest rate to one standard error shock are about the same as in the responses of real exchange rate in the four-variable case.

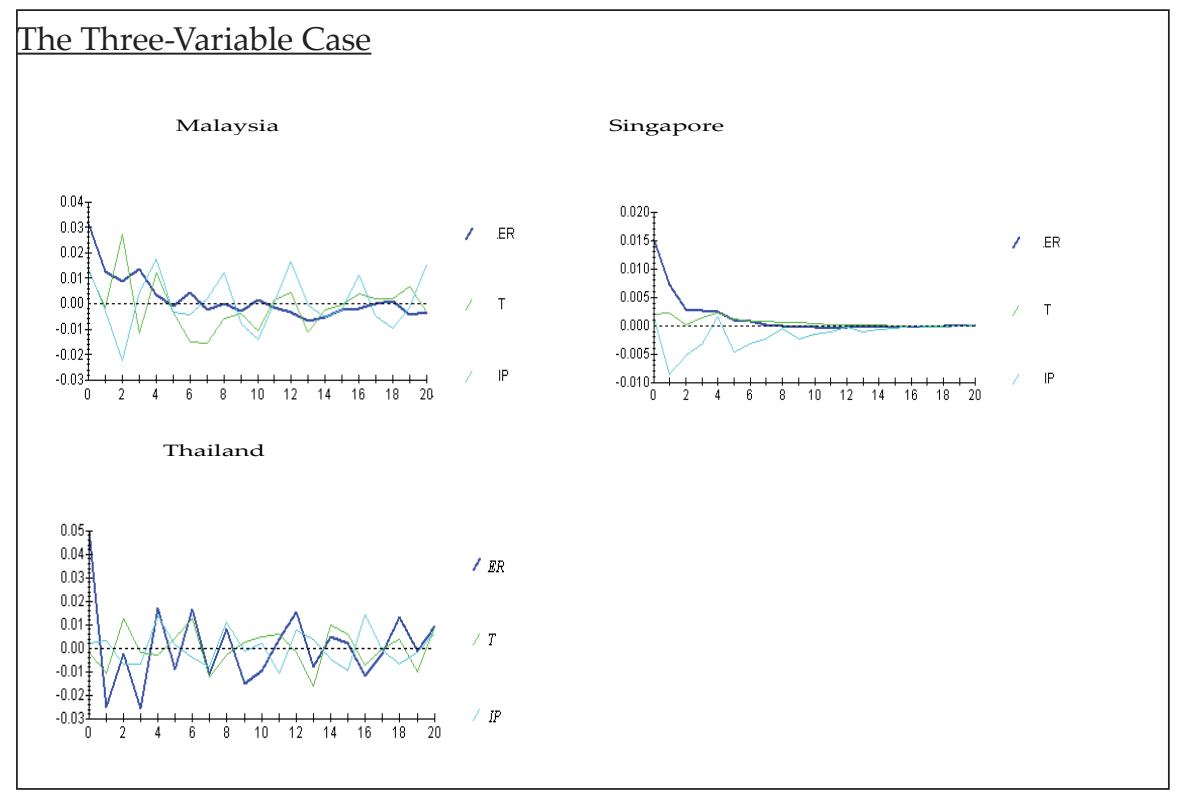

Figure 1: Plots of the generalised impulse response functions to one standard error shock in the equation for real exchange rate 
Figure 1 (continued)

The Four-Variable Case

Malaysia

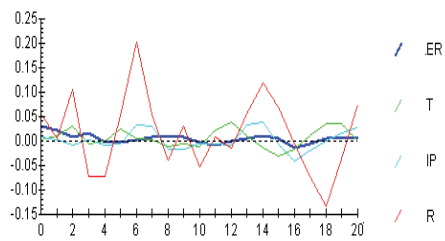

Thailand

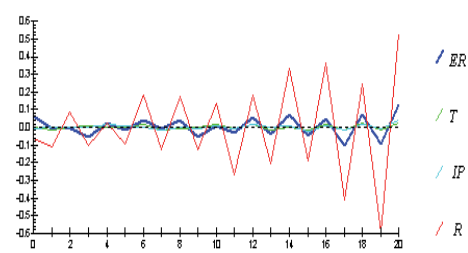

Singapore

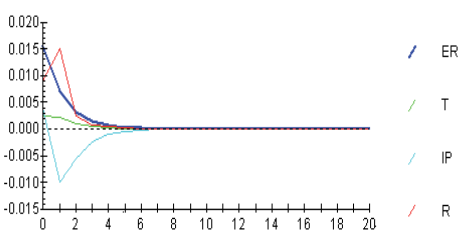

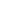

.

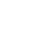

Notes: ER denotes $\Delta \log R E R_{t^{\prime}}$ T denotes $\Delta \log T O T_{t^{\prime}}$ IP denotes $\Delta \log R D_{t^{\prime}} \mathrm{R}$ denotes $\Delta \log R E R_{t}$.

\section{The Three-Variable Case}

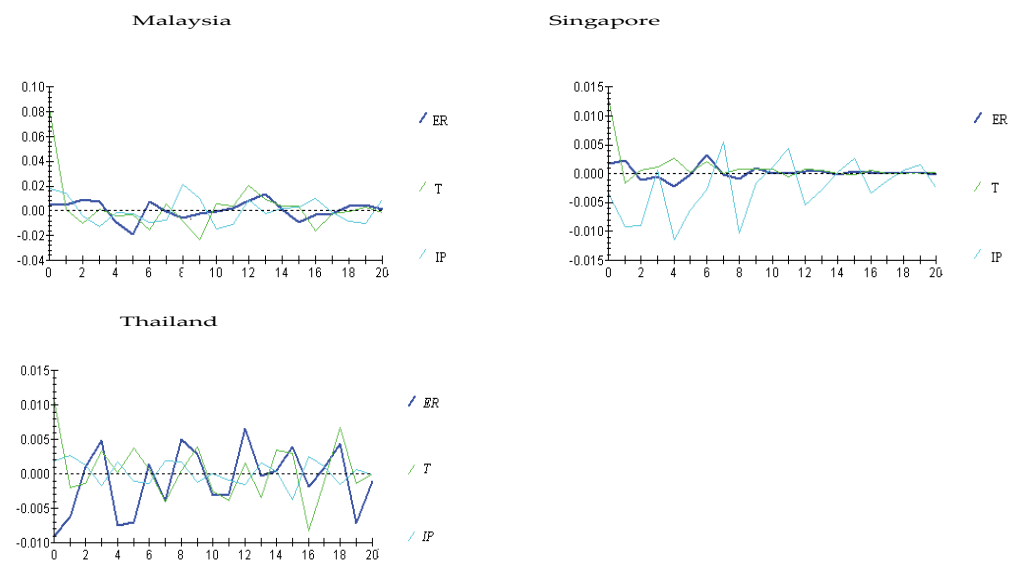

Figure 2: Plots of the generalised impulse response functions to one standard error shock in the equation for terms of trade 
Figure 2 (continued)

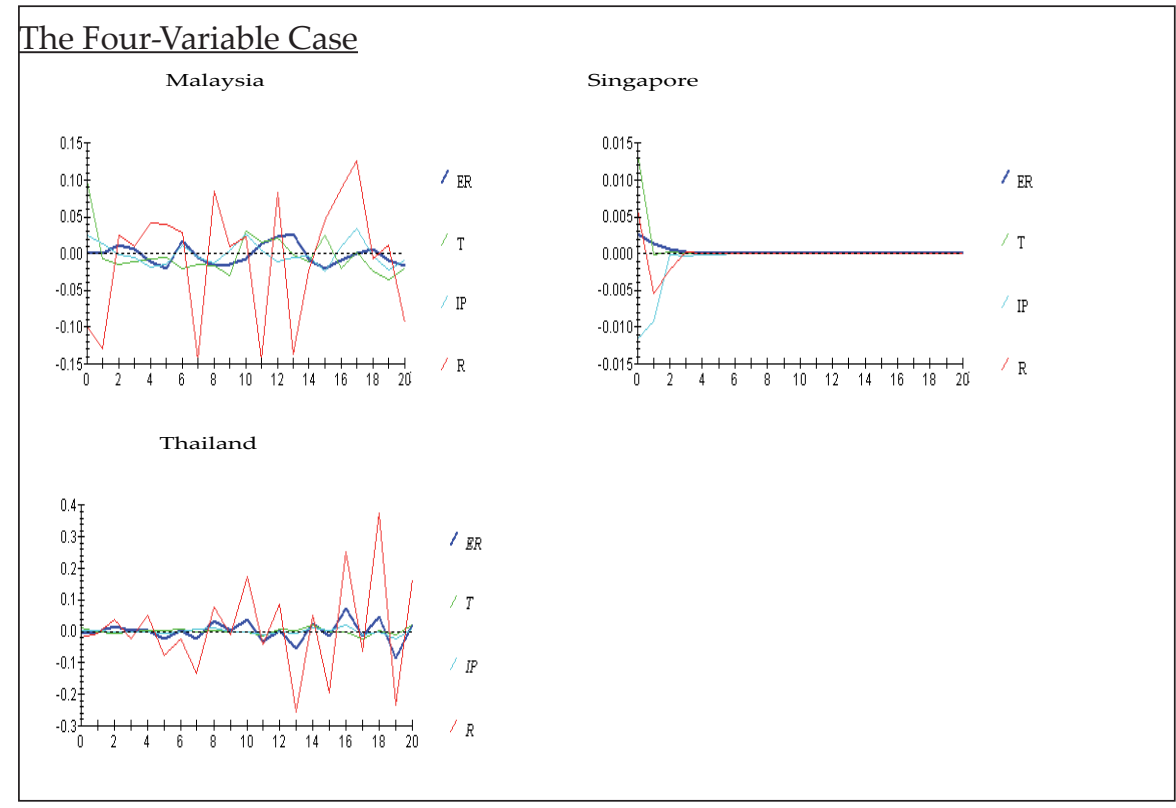

Note: See Figure 1 for explanation.

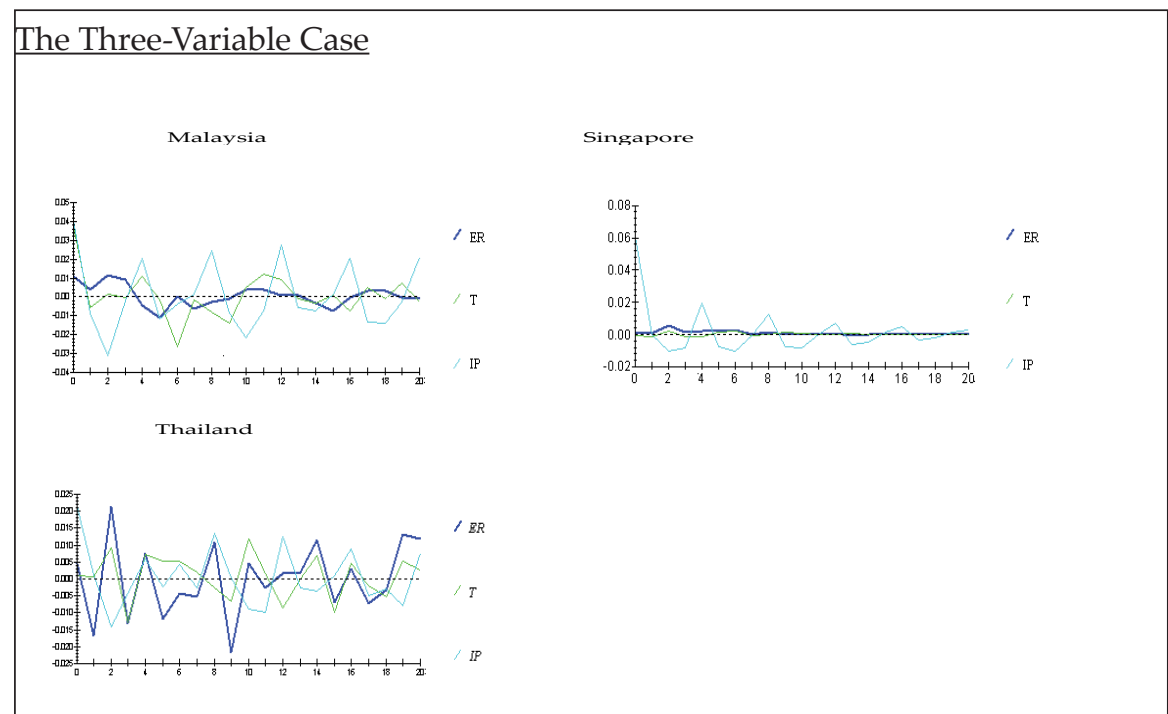

Figure 3: Plots of the generalised impulse response functions to one standard error shock in the equation for relative demand 
Figure 3 (continued)

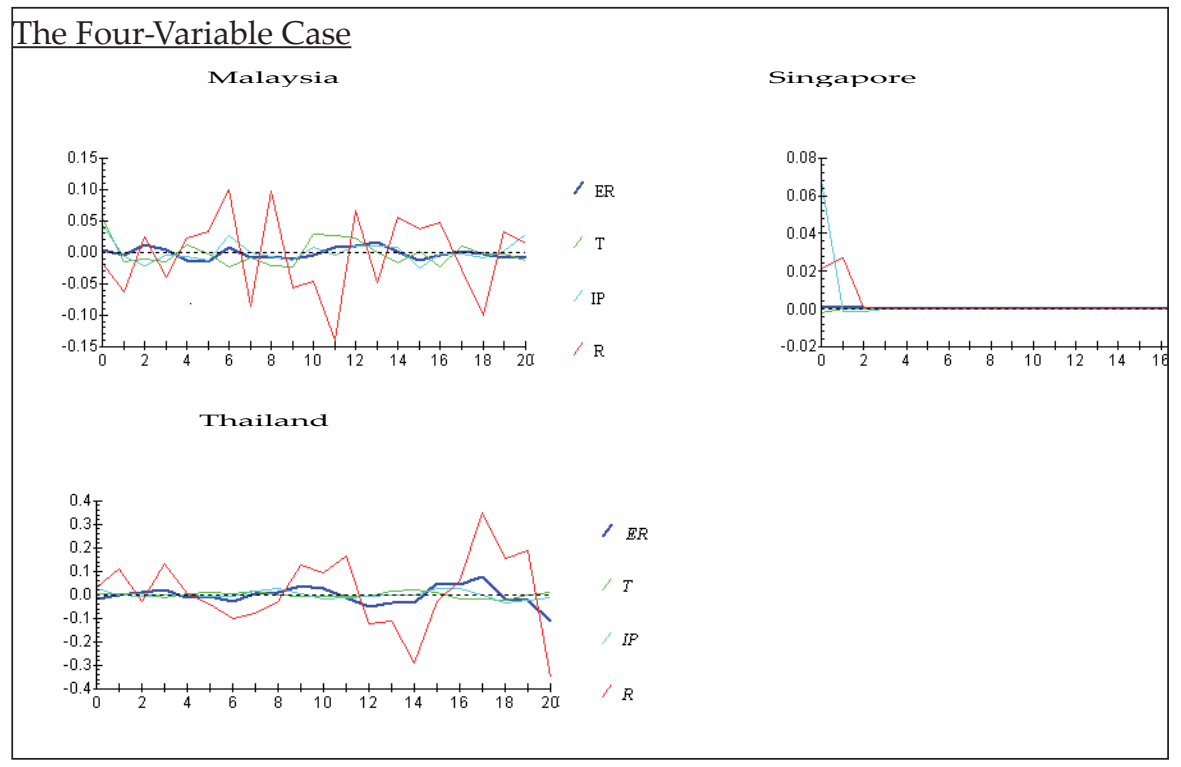

Note: See Figure 1 for explanation.

The Four-Variable Case

Malaysia

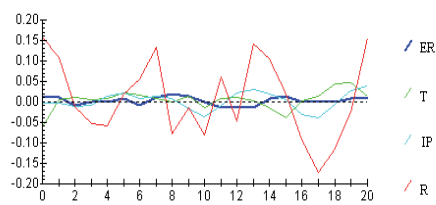

Thailand

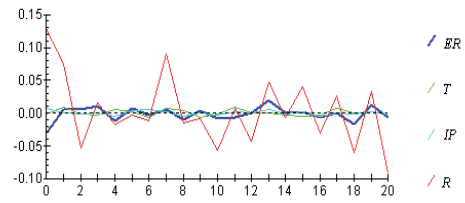

Singapore

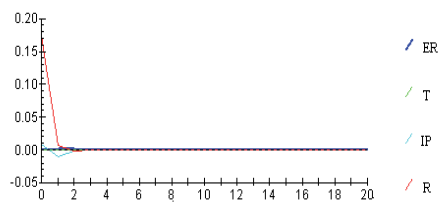

Note: See Figure 1 for explanation.

Figure 4: Plots of the generalised impulse response functions to one standard error shock in the equation for relative interest rate 
The impact of terms of trade on real exchange rate varies from economy to economy. Generally, the contribution of terms of trade to real exchange rate is greater than the contribution of relative demand for Singapore. The results are mixed for other economies. For Malaysia, the contribution of terms of trade to real exchange rate is smaller than the contribution of relative demand in the short-run but in the long-run, the contribution of terms of trade to real exchange rate is greater than the contribution of relative demand. For Thailand, the contribution of terms of trade to real exchange rate is smaller than the contribution of relative demand. Habermeier and Mesquita (1999) also reported that developing economies have smaller exchange rate impact from terms of trade than developed economies. Generally, the impact of terms of trade on real exchange rate is small. The different levels of importance of terms of trade across economies can be a good reason to examine an individual economy instead of a panel of economies. These findings are consistent with the findings of Devereux and Connolly (1996), amongst others. On the whole, innovation in each variable is explained mainly by its own innovation but varies across economies.

Generally, the contribution of relative real interest rate to real exchange rate is greater than the contribution of relative demand, except for Thailand. For Thailand (except from 0 to 5 horizon periods), the contribution of relative demand to real exchange rate is greater than the contribution of relative real interest rate. For Thailand, relative demand plays a more important role than terms of trade in the determination of real exchange rate. This finding is consistent with the finding of Choudhri and Khan (2005), amongst others that the Balassa-Samuelson hypothesis is empirically useful for investigating the long-run behaviour of real exchange rate for developing economies. Moreover, much of the variation in real exchange rate is attributable to the movement in terms of trade and the influence of relative real interest rate is small. This is consistent with the finding of Amano and Van Norden (1995), amongst others. There is weak evidence that the contribution of terms of trade on real exchange rate is higher in an economy that is more open to international trade. One explanation is that economic structures of the economies examined are not the same. Singapore is an industrialised economy and exports mainly higher valued products. Conversely, Malaysia and Thailand are generally developing economies and export mainly commodity or relatively low value-added products. Malaysia is relatively more open to international trade than Thailand (Table 1). Thus, the impact of terms of trade to these economies may not be the same. Generally, changes in export and import prices in the world markets will 
influence exchange rate of an economy especially when the economy is very open to international trade. Also, exchange rate of the economy is likely to be more volatile. Terms of trade is an important factor in the determination of exchange rate in the economy.

\section{CONCLUDING REMARKS}

The main aim of this study was to examine the relationship among real exchange rate, terms of trade, relative demand, and relative real interest rate in Malaysia, Singapore, and Thailand. The results of cointegration tests showed that there is a long-run relationship among real exchange rate, terms of trade, and relative demand for Malaysia and Thailand. Moreover, there is a long-run relationship among real exchange rate, terms of trade, relative demand, and relative real interest rate for Malaysia and Thailand. The results of Granger causality showed that real exchange rate does not Granger cause terms of trade in the VAR or VEC models, except that the result was mixed for Thailand.

The contribution of terms of trade and relative demand to real exchange rate is mixed and small. Generally, the contribution of terms of trade to real exchange rate is greater than the contribution of relative demand in Singapore. For Thailand, relative demand is more important than terms of trade in the determination of real exchange rate. For Malaysia, the results are mixed. Moreover, much of the variation in real exchange rate is attributable to the movement in terms of trade or relative demand, and the influence of relative real interest rate is small. Furthermore, variation, in each variable is explained mainly by its own innovation but, varies across economies.

\section{ACKNOWLEDGEMENTS}

The author would like to thank the reviewer of the journal for the comments on an earlier version of this paper. All remaining errors are the author's.

\section{ENDNOTES}

1. Aversion of this paper was presented at the International Conference on Businesss, Environment, International Competitiveness, and 
Sustainable Development of the Asia Pacific Economies, 3rd - 4th December 2007, Sunway Lagoon Resort Hotel, Selangor, organised by Monash University.

2. The time series evidence of the Balassa-Samuelson hypothesis for developing economies has been largely unexplored. One reason is that the relevant data are not readily available (Choudhri \& Khan, 2005; p. 388).

3. When series are not cointegrated, the testing of Granger causality shall be in the vector autoregressive models.

4. The Granger test is usually applied only to pairs of variables. Thus, the test could produce a misleading result when the true relationship involves three or more variables (both of the variables being tested are caused by a third or more variables and they may have no true relationship with each other, but give positive results in a Granger test). A similar test can be applied with the vector autoregressive models for more variables. However, the interpretation of the results shall be caution (Granger 1988; p.p. 206-208; http://en.wikipedia.org/wiki/Granger_causality).

5. For the four-variable case, the estimation of Granger causality is the same as the three-variable case, except when including an additional variable, namely relative real interest rate, and also there is one more vector autoregressive model or vector error correction model.

6. For Malaysia and Singapore, real effective exchange rate is used. For Thailand, real exchange rate is expressed by exchange rate multiplied by the relative domestic and the US consumer price.

7. For Malaysia and Thailand, domestic demand is expressed by industrial production. For Singapore, domestic demand is expressed by manufacturing production.

8. This study also had tried relative real interest rate, which is measured by relative real deposit rate. Generally, about the same conclusions were found as when using relative real interest rate, which was measured by relative real money market rate.

9. The generalised forecast error variance decomposition and generalised impulse response function are estimated from the 
vector autoregressive model if there is no evidence of cointegration whilst from the vector error correction model if there is evidence of cointegration.

\section{REFERENCES}

Amano, R. A., \& Van Norden, S. (1995). Terms of trade and real exchange rates: the Canadian evidence. Journal of International Money and Finance, 14(1), 83-104.

Bagchi, D., Chortareas, G. E., \& Miller, S. M. (2004). The real exchange rate in small, open, developed economies: Evidence from cointegration analysis. The Economic Record, 80(248), 76-88.

Balassa, B. (1964). The purchasing power parity doctrine: A reappraisal. Journal of Political Economy, 72, 584-596.

Broda, C. (2004). Terms of trade and exchange rate regimes in developing countries. Journal of International Economics, 63, 31-38.

Chen, S. S., \& Chen, H. C. (2007). Oil prices and real exchange rates. Energy Economics, 29, 390-404.

Choudhri, E. U., \& Khan, M. S. (2005). Real exchange rates in developing countries: Are Balassa-Samuelson effects present? IMF Staff Papers, 52(3), 387-409.

Devereux, J., \& Connolly, M. (1996). Commercial policy, the terms of trade and the real exchange rate revisited. Journal of Development Economics, 50, 81-99.

Dickey, D. A., \& Fuller, W. A. (1979). Distribution of the estimators for autoregressive time series with a unit root. Journal of the American Statistical Association, 74(366), 427-431.

Dungey, M. (2004). Identifying terms of trade effects in real exchange rate movements: Evidence from Asia. Journal of Asian Economics, $15,217-235$.

Granger, C. W. J. (1969). Investigating causal relations by econometric models and cross spectral models. Econometrica, 37, 424-438.

Granger, C. W. J. (1988). Some recent development in a concept of causality. Journal of Econometrics, 39, 199-211.

Habermeier, K., \& Mesquita, A. (1999). Long-run exchange rate dynamics: A panel data study. IMF Working Paper, 99/50.

Johansen, S. (1988). Statistical analysis of cointegration vectors. Journal of Economic Dynamics and Control, 12(2-3), 231-254.

Johri, A., \& Lahiri, A. (2008). Persisten real exchange rates. Journal of International Economics.

Koop, G., Pesaran, M. H., \& Potter, S. M. (1996). Impulse response analysis in nonlinear multivariate models. Journal of Econometrics, 74, 119147. 
Levich, R. M. (2001). International financial markets: Prices and policies (2nd ed.). Singapore: McGraw-Hill International Edition.

MacKinnon, J. G. (1996). Numerical distribution functions for unit root and cointegration tests. Journal of Applied Econometrics, 11(6), 601618.

Pesaran, H., \& Shin, Y. (1998). Generalised impulse response analysis in linear multivariate models. Economics Letters, 58, 17-29.

Pesaran, M. H., Shin, Y., \& Smith, R. J. (2000). Structural analysis of vector error correction models with exogenous I(1) variables. Journal of Econometrics, 97, 293-343.

Phillips, P. C. B., \& Perron, P. (1988). Testing for a unit root in time series regression. Biometrika, 75(2), 335-346.

Sager, M. (2006) Explaining the persistence of deviations from PPP: A non-linear Harrod-Balassa-Samuelson effect? Applied Financial Economics, 16, 41-61.

Samuelson, P. A. (1964). Theoretical notes on trade problems. Review of Economics and Statistics, 46, 145-154.

Sebastian, E., \& Van Wijnbergen, S. (1987). Tariffs, the real exchange rate, and the terms of trade: On two popular propositions in international economics. NBER Working Paper No. 2365.

Sims, C. (1980). Macroeconomics and reality. Econometrica, 48, 1-48.

Swift, R. (2004). Exchange rate changes and endogenous terms of trade effects in a small open economy. Journal of Macroeconomics, 26, 737-745. 